\title{
EMERALDS FROM THE FAZENDA BONFIM Region, Rio Grande do Norte, Brazil
}

J. C. (Hanco) Zwaan, Dorrit E. Jacob, Tobias Häger, Mário T. O. Cavalcanti Neto, and Jan Kanis

In 2006, emeralds were discovered in the Fazenda Bonfim region of northeastern Brazil. Emerald mineralization occurs in association with small recrystallized pegmatitic bodies hosted by metamorphosed ultramafic rocks within the Santa Monica Shear Zone. Prospecting and exploration have been carried out in a few small pits and tunnels, producing emerald crystals with transparent areas that typically range between 2 and $5 \mathrm{~mm}$. Polished samples typically show a saturated bluish green color with a medium-light to medium tone. The most common internal features are partially healed fissures with two-phase (liquid-gas) fluid inclusions and a variety of fine, parallel-oriented growth tubes. The emeralds contain moderate amounts of the chromophore elements $\mathrm{Cr}$ and $\mathrm{Fe}$, and traces of $\mathrm{V}$; they also show relatively high $\mathrm{K}$ and low Li. FTIR spectroscopic features are consistent with alkali-bearing emeralds that contain considerable $\mathrm{CO}_{2}$ and a small amount of deuterated water. Emeralds from Fazenda Bonfim can be distinguished from those of other schist- and pegmatite-related commercial deposits.

B razil is an important emerald producer. Wellknown deposits occur in the states of Minas Gerais (Belmont, Piteiras, and Capoeirana-see Hänni et al., 1987; Epstein, 1989; Souza et al., 1992; Kanis, 2002; Rondeau et al., 2003); Bahia (Socotó and Carnaíba—see Schwarz 1990b; Eidt and Schwarz, 1988; Giuliani et al., 1990; Giuliani et al., 1997); and Goiás (Santa Terezinha-see Cassedanne and Sauer, 1984; Schwarz 1990a; Giuliani et al., 1990 and 1997). In the northeastern part of Brazil, emeralds are known from near Tauá in Ceará State, but they are not of high quality (Schwarz et al., 1988).

In Rio Grande do Norte State, rare-element mineralized granitic pegmatites have been known since the pioneering work of Johnston (1945) and Rolff (1946) in the Borborema Pegmatitic Province. In 2006, a team led by one of the present authors discovered emeralds in the Fazenda Bonfim region (figure 1; Cavalcanti Neto

See end of article for About the Authors and Acknowledgments.

Gems \& Gemology, Vol. 48, No. 1, pp. 2-17,

http://dx.doi.org/10.5741/GEMS.48.1.2.

(C) 2012 Gemological Institute of America and Barbosa, 2007). The team was hired by Emprogeo Ltd. (Natal, Brazil) to explore for chromium, nickel, and platinum mineralization associated with ultramafic rocks, which were known to be present but had never been properly mapped. Emeralds were found in an area where geologists had previously focused on gold and rare-element mineralization. Several mines in this region (near the municipality of Lajes) had produced beryl and/or columbite-tantalite from pegmatites, but without any attention to the potential of ores related to ultramafic rocks.

After the discovery of emeralds in the Fazenda Bonfim region, Mineração Vale Verde Ltd. (registered in June 2006) acquired the mining rights from Emprogeo Ltd. Exploration of the area, which comprises nearly 656 hectares, started in August 2006. Mineração e Comércio Itaobi Ltda. also owns several licenses close to this area, and Mineração Santo Expedito Ltda. is the holder of a nearby gold, tungsten, and bismuth mining concession. All have invested heavily in mineral exploration (sampling, drilling, mapping, and geochemical surveys). Despite these efforts and promising early results, the emerald mine has not yet begun production. 


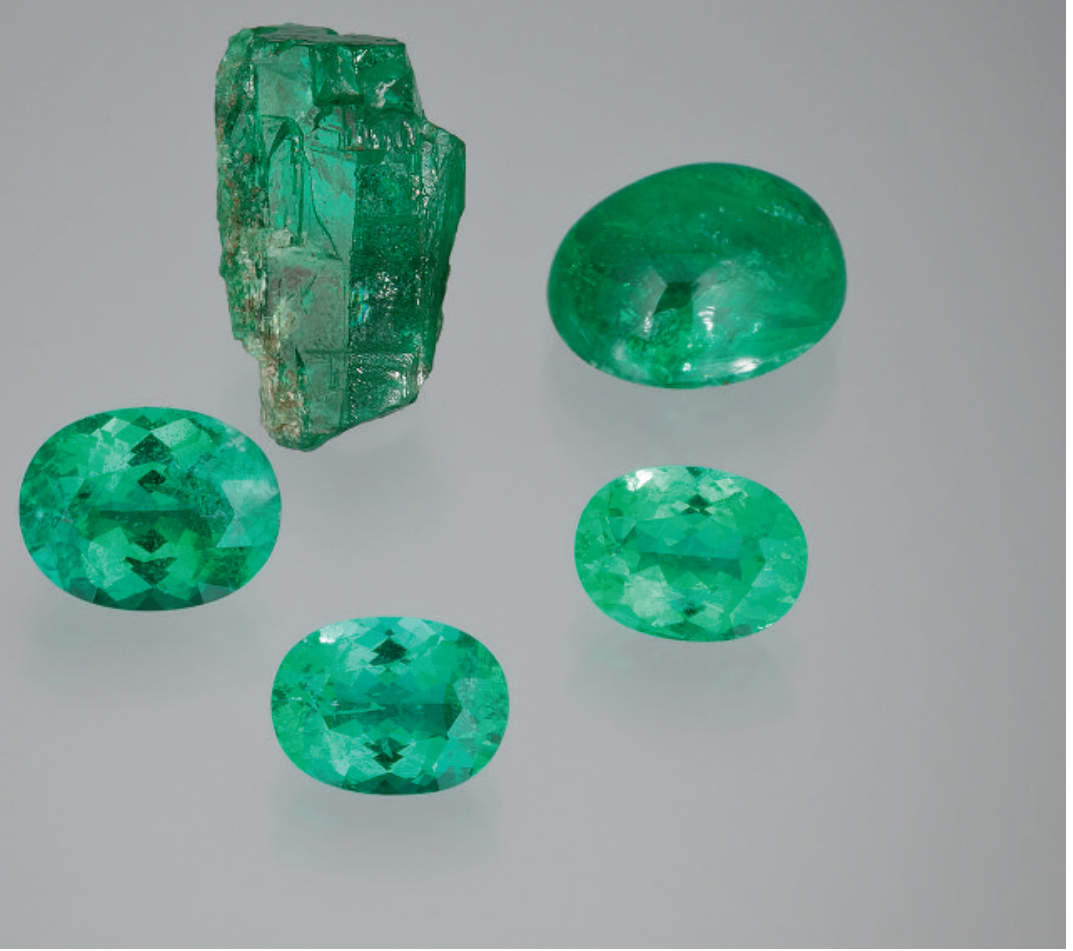

Figure 1. A limited amount of emeralds have so far been produced from the Fazenda Bonfim region in Brazil's Rio Grande do Norte State. The faceted stones shown here weigh 1.29-1.92 ct, and the cabochon weighs 3.89 ct. Photo by Robert Weldon.

Gemological properties of faceted light to dark green emeralds weighing up to $10 \mathrm{ct}$ that were reportedly from this area were briefly described by Milisenda (2007). The present article characterizes the gemological properties of the emeralds from Fazenda Bonfim in detail and introduces chemical data. Information on the geology and mining was gathered by authors JCZ and JK over the course of a seven-day visit to the Fazenda Bonfim mining area in July 2009, and updated information on the situation at the deposit was supplied by Mineração Vale Verde Ltd.

\section{LOCATION AND ACCESS}

The Fazenda Bonfim region lies west of Natal, the state capital of Rio Grande do Norte, between the municipalities of São Tomé, Caiçara do Rio do Vento, and Lajes. The emerald deposit is located near the Bonfim gold-tungsten mine (figure 2), at coordinates $05^{\circ} 50.45^{\prime} \mathrm{S}$, $036^{\circ} 07.10^{\prime} \mathrm{W}$ and an elevation of $\sim 420 \mathrm{~m}$. From Natal, the workings can be reached by driving about $95 \mathrm{~km}$ west to Caiçara do Rio do Vento, then another $6 \mathrm{~km}$ west on a paved road. A dirt track then proceeds about $18 \mathrm{~km}$ south to the mining area.

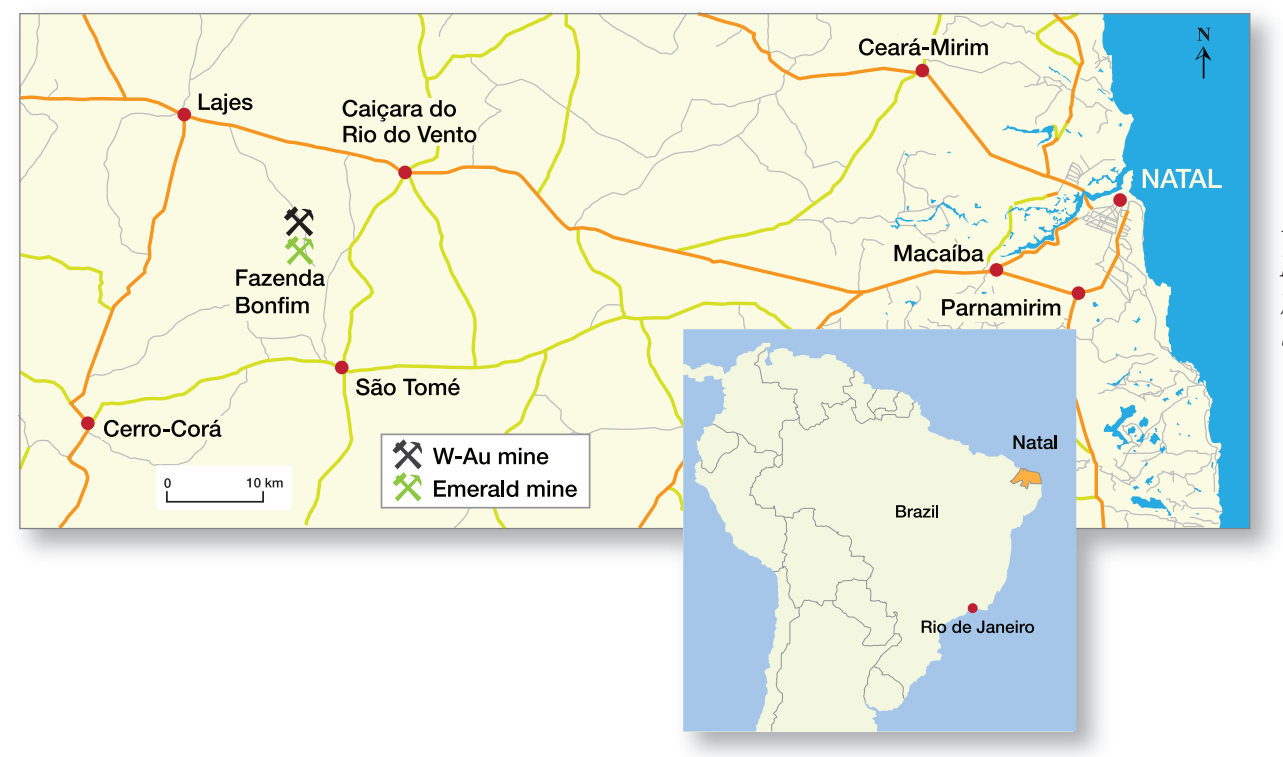

Figure 2. The emerald deposit in the Fazenda Bonfim region is located southwest of the village of Caiçara do Rio do Vento. 

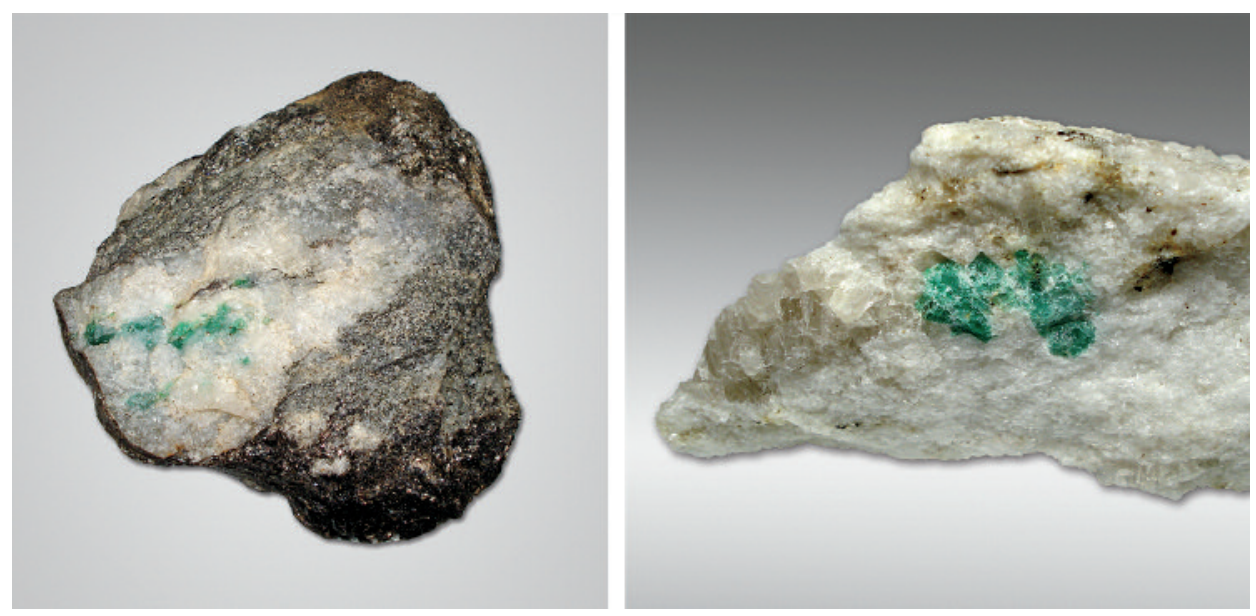

Figure 5. Emeralds commonly occur near the contact between recrystallized pegmatite and biotite schist, as shown in the 15$\mathrm{cm}$-wide specimen on the left. The recrystallized pegmatitic rocks, mainly consisting of sodium-rich feldspar and quartz veins, show a saccharoidal texture and may also contain emeralds (right, image width $11.5 \mathrm{~cm})$. Photos by J. C. Zwaan.

Emerald mineralization is associated with ultramafic to mafic rocks (metamorphosed into amphibolites) within the Santa Monica Shear Zone. These rocks are located at relatively higher altitude $(>400 \mathrm{~m})$ in the resistant granite gneiss basement. Adjacent to the amphibolites is a succession of talc, talc-amphibole, and biotite \pm amphibole schists, with a sharp contact between biotite schist and granitic gneiss (figure 4). The biotite schist layers range from $0.2 \mathrm{~m}$ to more than 3 $\mathrm{m}$ thick, and dip northwest rather steeply at $38^{\circ}-56^{\circ}$. Small recrystallized pegmatitic bodies are present in the schist, near the contact with the granitic gneiss. Emeralds occur in and around those bodies, particularly within the biotite schist.

The recrystallized pegmatitic veins have a saccharoidal texture and are generally homogeneous, mainly consisting of sodium-rich plagioclase, though they also contain narrow quartz veins (typically up to a few centimeters wide). The emeralds within the recrystallized pegmatites are often small $(<1 \mathrm{~cm})$ and light-medium to medium bluish green (figure 5). The better-color emeralds appear to be associated particularly with the narrow quartz veins within the recrystallized pegmatites.

The recrystallized nature of the pegmatitic veins (compare, e.g., Giuliani et al., 1990; Zwaan, 2006) clearly indicates that metasomatic reactions with the schist played an important role in bringing the vital elements together to form emerald (Cr from the ultramafic rocks, and $\mathrm{Be}, \mathrm{Al}$, and Si from the veins). Detailed study of the area's geology is being undertaken to better understand the mechanisms and conditions of emerald formation.

\section{EXPLORATION AND MINING}

Prospecting is hindered by dense vegetation, which also limits the use of satellite imagery. A geochemical survey of soil samples (Scholz, 2008) revealed that $\mathrm{Cr}$ and $\mathrm{Be}$ anomalies follow the orientation of the Santa Monica Shear Zone. The highest values of both elements were found in the central part of the Fazenda Bonfim deposit, in the same area that has been worked so far. Anomalies also have been found farther north and northeast. A core drilling program of the mining area consisted of 33 holes (47 mm diameter) for a total length of 1,115 m. Further exploration has been carried out, using hand tools, in a few small pits and adits along the ultramafic/granitic gneiss contact (figure 6). The surface exposure showing potential for new mineralization extends no more than $700 \mathrm{~m}$, and additional tunneling along the contact is needed to further explore the downward extension of the narrow zone of emerald mineralization.

Figure 6. This overview of the emerald mining area shows small pits and adits along the ultramafic/granitic gneiss contact. Photo by J. C. Zwaan.

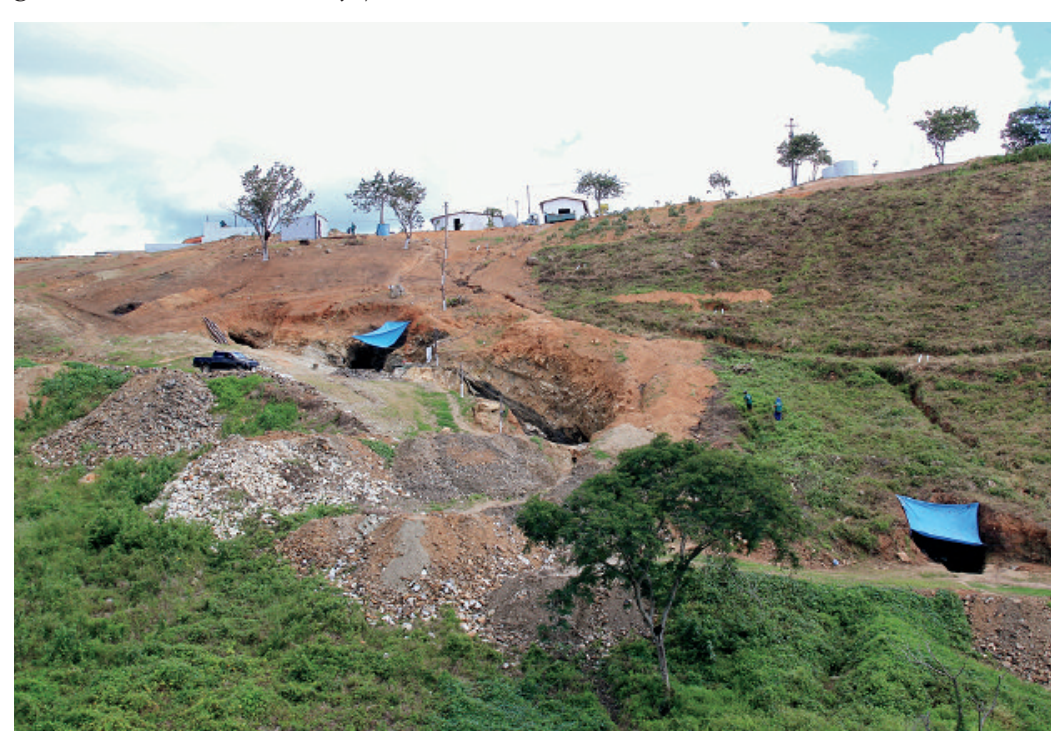



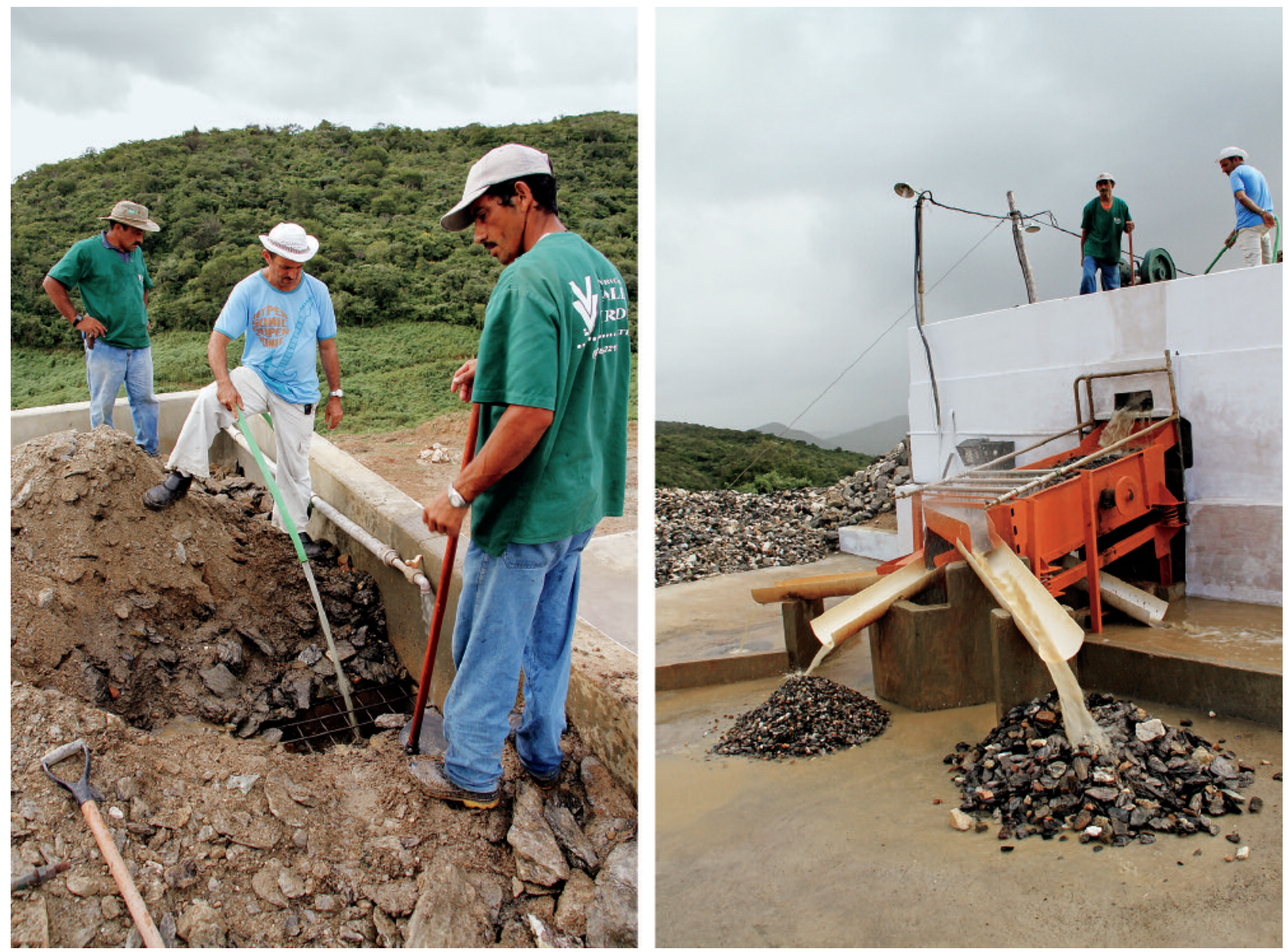

Figure 7. A basic processing plant has been used onsite to wash and sort the mined material in search of emeralds. Photos by J. C. Zwaan.

Material from the pits dug so far has been processed with a basic washing and sorting plant, built onsite (figure 7). Part of this material also was transported to Caiçara do Rio do Vento, where more than 20 women sorted through 2.5 tonnes/day of ore, collecting 100150 grams of beryl/emerald daily (J. Amancio Nery, pers. comm.; e.g., figure 8); this averages 50 grams per tonne. An internal report by Mineração Vale Verde Ltd. (Scholz, 2008) stated a figure of $10.5 \mathrm{~kg} /$ tonne, but this was based on testing of only $127.8 \mathrm{~kg}$ of mineralized rock. The production on the day of our visit to the sorting area was particularly low, but material of better quality and quantity from previous days was presented at the company's offices.

Mineração Vale Verde Ltd. has invested in the infrastructure necessary for a well-organized mining operation, such as running water, electricity, housing, an explosives magazine, and a repair shop. However, a dispute over the ownership rights has temporarily suspended activities. The case was resolved in Novem- ber 2011, and operations are expected to resume in early 2012, after the rainy season.

The discovery of emeralds has stimulated additional geologic studies of the Lajes region, through a collaboration between the Federal University of Rio Grande do Norte, the Geological Survey of Brazil and other governmental parties, and Mineração Vale Verde Ltd. The Geological Survey is mapping the area around Lajes on a $1: 100,000$ scale to locate other ultramafic and recrystallized pegmatitic bodies. The aim is to obtain a detailed geologic map of this region and finally to create a prospecting guide for mining entrepreneurs.

\section{DESCRIPTION OF THE ROUGH}

Fazenda Bonfim emeralds typically consist of crystal fragments with homogeneous color. Well-formed crystals showing hexagonal prisms are rarely recovered as broken segments that commonly lack flat (pinacoidal) terminations. Transparent fragments and crystals (figure 9) typically range between 2 and $5 \mathrm{~mm}$, though larger 


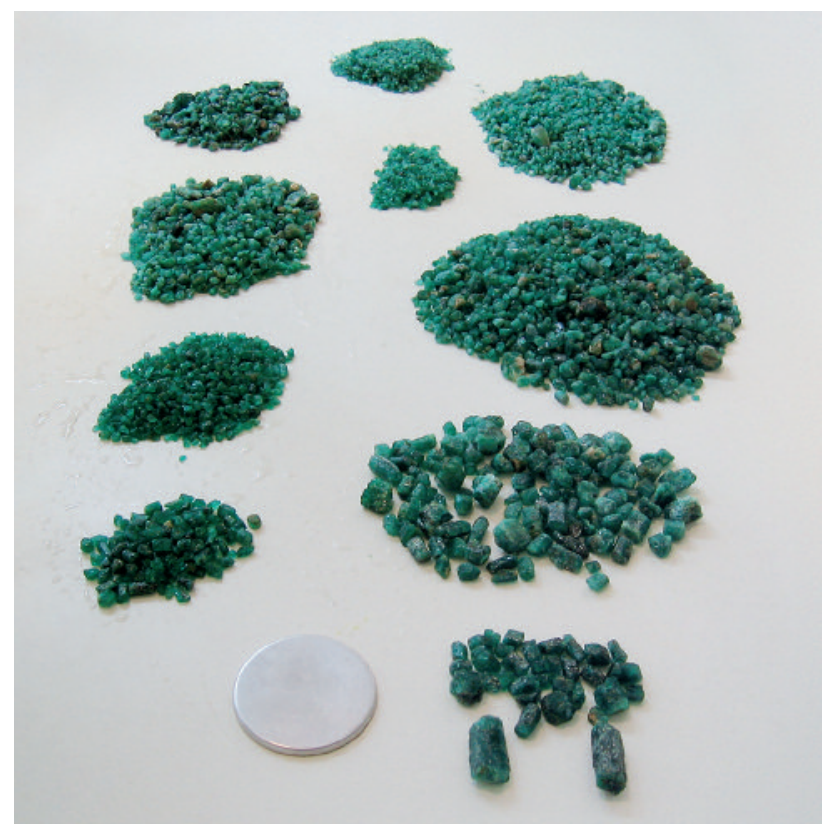

Figure 8. Some of the emerald obtained from material processed in the washing plant is shown here. The large crystals on the lower right are $5 \mathrm{~cm}$ long. Courtesy of Mineração Vale Verde Ltd.

included crystals measuring a few centimeters long have been found.

The color of the emeralds ranges from light slightly bluish green to medium-dark bluish green. Very pale green beryl is also found.

\section{MATERIALS AND METHODS}

For this study, we examined 41 samples from Fazenda Bonfim, including 11 pieces of emerald rough that were transparent and suitable for faceting and 15 thin sections

Figure 9. The emerald fragments and crystals recovered from the Fazenda Bonfim deposit are typically small but of homogeneous color. The piece at the front-left is $10 \mathrm{~mm}$ wide. Photo by Dirk van der Marel.

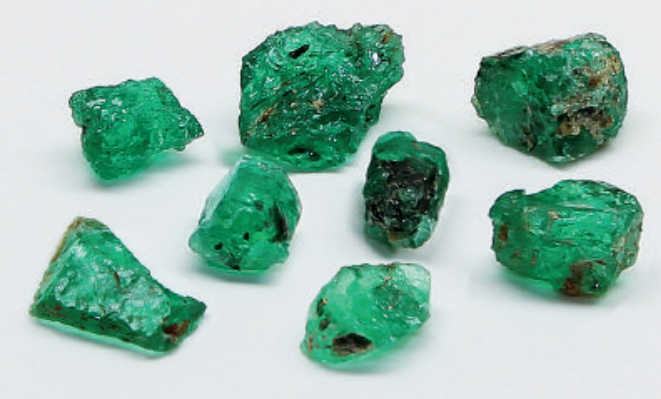

made from emerald-bearing rock; all of this material was collected by author JCZ during his visit to the mine. Parallel plates were cut and polished from three of the rough pieces for spectroscopy, whereas the thin sections were used only for studying inclusions in the emerald grains. In addition, 14 faceted and one cabochon-cut emerald, ranging from 0.17 to $3.89 \mathrm{ct}$, were obtained from Mineração Vale Verde Ltd. for this investigation.

Analyses done at the Netherlands Gemmological Laboratory included standard gemological testing and UV-Vis-NIR, FTIR, and Raman spectroscopy. A Rayner refractometer (yttrium aluminum garnet prism) with a near sodium-equivalent light source was used to measure refractive index and birefringence, specific gravity was determined hydrostatically, a calcite dichroscope revealed pleochroic colors, long- and short-wave UV lamps were used in a darkened room to observe fluorescence, and absorption spectra were visualized with a System Eickhorst M9 spectroscope with a builtin light source. Internal features were observed with a standard gemological microscope and a Nikon Eclipse E600 POL polarizing microscope.

Inclusions in 15 samples were analyzed by Raman spectroscopy using a Thermo DXR Raman microscope with $532 \mathrm{~nm}$ laser excitation. UV-Vis-NIR absorption spectra of six representative samples (one cabochon, two faceted, and three parallel plates) were taken with a Unicam UV 540 spectrophotometer in the $280-850 \mathrm{~nm}$ range. Mid-IR spectra of 16 representative samples (one cabochon, 14 faceted, and one parallel plate) were collected using a Thermo Nicolet Nexus FT-IR-NIR spectrometer.

Quantitative chemical analyses (46 spots) were carried out on 15 faceted emeralds at the electron microprobe facility of the Institute of Earth Sciences, Free University of Amsterdam, using a JEOL model JXA$8800 \mathrm{M}$ instrument. Analyses were performed at $15 \mathrm{kV}$, with a beam current of $25 \mathrm{nA}$ and a spot size of $3 \mu \mathrm{m}$. The count time was 25 seconds for major elements and 36 seconds for most trace elements $(50$ seconds for $\mathrm{V}$, $\mathrm{Cr}$, and $\mathrm{Rb}$ ).

Trace-element chemical data of 24 samples $(15$ faceted and 9 rough) were measured quantitatively by laser ablation-inductively coupled plasma-mass spectrometry (LA-ICP-MS) at the Johannes Gutenberg University's Institute of Geosciences using an Agilent 7500ce quadrupole ICP-MS coupled with a New Wave Research NWR-193 laser ablation system (193 nm wavelength). Ablation was carried out with helium as the carrier gas at an energy density of $2.77 \mathrm{~J} / \mathrm{cm}^{2}$, a pulse rate of $10 \mathrm{~Hz}$, and a $50 \mu \mathrm{m}$ crater size. NIST SRM 610 and 612 glass reference materials were used as external standards, and 
TABLE 1. Physical properties of emeralds from Fazenda Bonfim, Rio Grande do Norte, Brazil.

\begin{tabular}{|c|c|}
\hline Color & $\begin{array}{l}\text { Very light to medium-dark slightly bluish green to strongly bluish green; typically a saturated bluish green with a } \\
\text { light-medium to medium tone }\end{array}$ \\
\hline Clarity & Very slightly to heavily included \\
\hline Refractive indices & $\mathrm{n}_{\mathrm{o}}=1.587-1.591 ; \mathrm{n}_{\mathrm{e}}=1.578-1.583$ \\
\hline Birefringence & $0.008-0.009$ \\
\hline Specific gravity & $2.72-2.74$ \\
\hline Pleochroism & Distinct to strong; (light) yellowish green (o-ray), and bluish green to greenish blue (e-ray) \\
\hline Fluorescence & Inert to long- and short-wave UV radiation \\
\hline Chelsea filter & Pink to red (stones with saturated colors) or no reaction \\
\hline Visible spectrum & Distinct lines at 636, 662, and $683 \mathrm{~nm}$; partial absorption between 580 and $630 \mathrm{~nm}$; and complete absorption $<430 \mathrm{~nm}$ \\
\hline Internal features & $\begin{array}{l}\text { - Often homogeneous color distribution, but moderate color zoning may occur as planar zones oriented parallel to the } \\
\text { - Prism faces } \\
\text { - Nartially healed fissures with two-phase inclusions-typically square, rectangular, or comma-like } \\
\text { - Partially decrepitated inclusions } \\
\text { - Parallel growth tubes } \\
\text { - Extremely fine unidentified fiber-like inclusions } \\
\text { - Mineral inclusions: rounded crystals of sodic plagioclase, platelets of phlogopite, thin flakes of hematite, and } \\
\text { clusters of minute grains of quartz }\end{array}$ \\
\hline
\end{tabular}

${ }^{29} \mathrm{Si}$ was the internal standard. Data reduction was carried out using GLITTER 4.0 software (Macquarie University, Sydney, Australia). An average $\mathrm{SiO}_{2}$ concentration of $63.5 \mathrm{wt}$.\% was used, based on electron microprobe data. For comparison with the Fazenda Bonfim emeralds, we also collected LA-ICP-MS data on emeralds from two additional pegmatite-related deposits: Kafubu, Zambia (21 samples) and Sandawana, Zimbabwe (16 samples). The data reduction process for these localities used average $\mathrm{SiO}_{2}$ concentrations of 63.0 and $62.8 \mathrm{wt} . \%$, respectively (based on published electron microprobe and PIXE data; e.g., Zwaan et al., 1997, 2005; Calligaro et al., 2000). Detection limits were typically in the lower parts per billion range, and analytical uncertainties were generally between $5 \%$ and $15 \%$, based on the external reproducibility of the reference materials (Jacob, 2006).

Figure 10. The polished emeralds studied for this report represented a range of sizes, from 0.17 to $3.89 \mathrm{ct}$, and were an attractive saturated light to mediumdark bluish green. Photo by Dirk van der Marel.

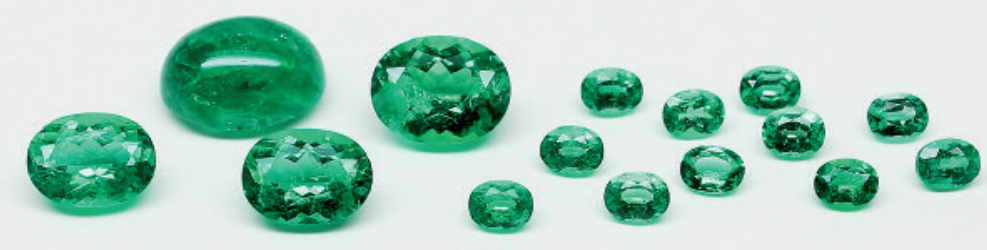

\section{GEMOLOGICAL PROPERTIES}

The gemological properties are summarized in table 1 , with details described below.

Visual Appearance. The polished emeralds ranged from slightly bluish green to strongly bluish green, with a very light to medium-dark tone. Many were an attractive saturated bluish green with a light-medium to medium tone. The samples were very slightly to heavily included, and most of them were small $(<0.20 \mathrm{ct})$. However, some of the faceted stones weighed nearly $2 \mathrm{ct}$ and a $3.89 \mathrm{ct}$ cabochon was also examined (figure 10). The color was evenly distributed, though moderate color zoning was observed in some rough fragments and polished material.

Physical Properties. Refractive indices were $\mathrm{n}_{\mathrm{o}}=1.587-$ 1.591 and $\mathrm{n}_{\mathrm{e}}=1.578-1.583$, yielding a birefringence of $0.008-0.009$. Specific gravity varied between 2.72 and 2.74. The emeralds were inert to long- and short-wave UV radiation. All of the samples with more saturated colors appeared pink to red under the Chelsea filter, while the others showed no reaction. Dichroism was distinct to strong, in (light) yellowish green and bluish green to greenish blue.

The visible spectra of most of the emeralds had distinct lines at $\sim 636,662$, and $683 \mathrm{~nm}$, partial absorption between 580 and $630 \mathrm{~nm}$, and complete absorption in the violet range $(<430 \mathrm{~nm})$. Small, light-colored emeralds showed a weaker spectrum with a clear line at $683 \mathrm{~nm}$.

Microscopic Characteristics. The most commonly encountered inclusions were partially healed fissures with two-phase fluid inclusions (aquo-carbonic fluid 
and gas) that were typically square, rectangular or comma-like (figure 11). Many of the emeralds had fine growth tubes oriented parallel to the c-axis. Occasionally observed were hexagonal-shaped negative crystals with a large bubble containing $\mathrm{CO}_{2}$ (determined by Raman microspectroscopy; figure 12). Some fluid inclusions had an irregular shape with signs of shrinkage

\section{In Brief}

- Emerald mineralization at Fazenda Bonfim occurs in association with small recrystallized pegmatitic bodies and biotite schist.

- Exploration activities have produced a small amount of material from shallow pits and tunnels.

- The emeralds are typically small but show attractive color with moderate $\mathrm{Cr}$ and $\mathrm{Fe}$, and low V. Relatively high $\mathrm{K}$ and $\mathrm{Cs}$ and low $\mathrm{Li}$ and $\mathrm{Na}$ separate them from other pegmatite-associated emeralds.

- Two-phase fluid inclusions and fine growth tubes are common, and FTIR spectra show characteristics of alkalis, $\mathrm{CO}_{2}$, and deuterated water.

or were partially decrepitated and empty (figure 13). Unidentified extremely fine curved fiber-like inclusions, more or less parallel-oriented, also occurred in a few samples. Six stones showed evidence of clarity enhancement (three minor, three moderate).

Figure 11. Arrays of square or rectangular two-phase inclusions were widespread in the Fazenda Bonfim emeralds. Fine parallel-oriented growth tubes were also observed in many of the samples. Photomicrograph by J. C. Zwaan; image width $1.4 \mathrm{~mm}$.

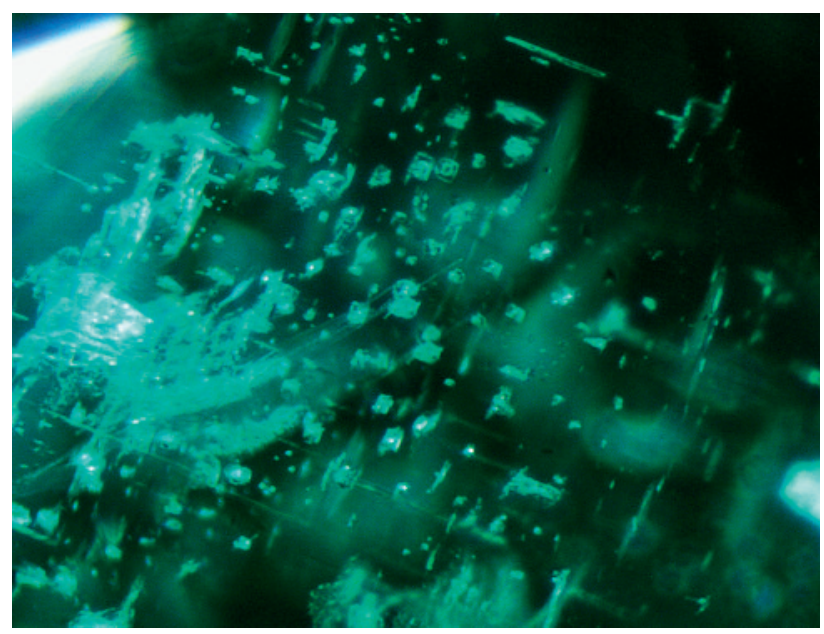

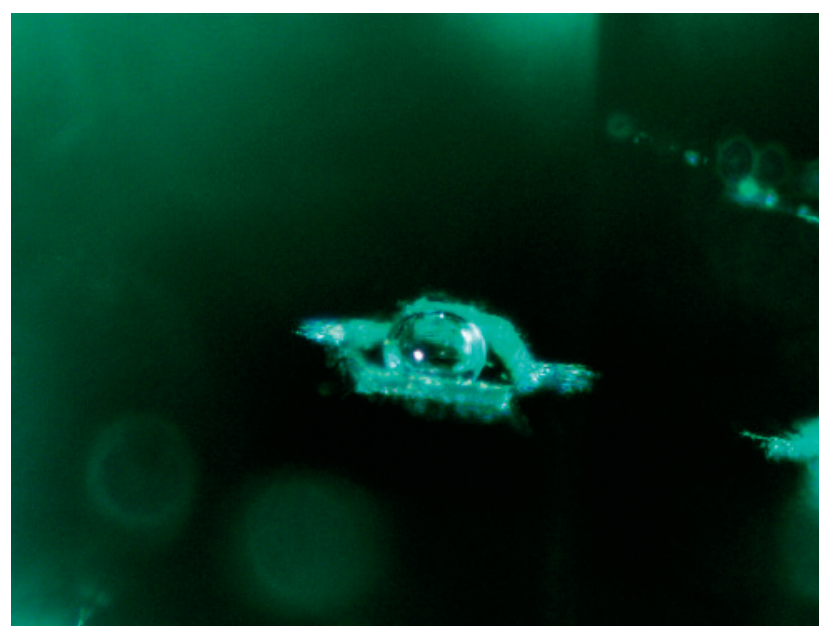

Figure 12. Raman microspectroscopy showed the presence of $\mathrm{CO}_{2}$ within large gas bubbles in hexagonalshaped negative crystals. Photomicrograph by J. C. Zwaan; image width $0.8 \mathrm{~mm}$.

Solid inclusions were uncommon. Inclusions of plagioclase (figure 14) had Raman spectra consistent with albite or oligoclase. Platelets of phlogopite (figure 15, left) and hematite were also observed, as well as minute inclusions of quartz (figure 15, right). Occasionally, fluid inclusions contained captured minerals that were doubly refractive under crossed polarizers. In one case, the captured minerals were identified by Raman analysis as carbonate and mica (probably magnesite and muscovite), and also bertrandite (figures 16 and 17).

Figure 13. These irregular fluid inclusions show signs of shrinkage; on the left side is a decrepitated and empty inclusion. Photomicrograph by J. C. Zwaan; image width $0.35 \mathrm{~mm}$.

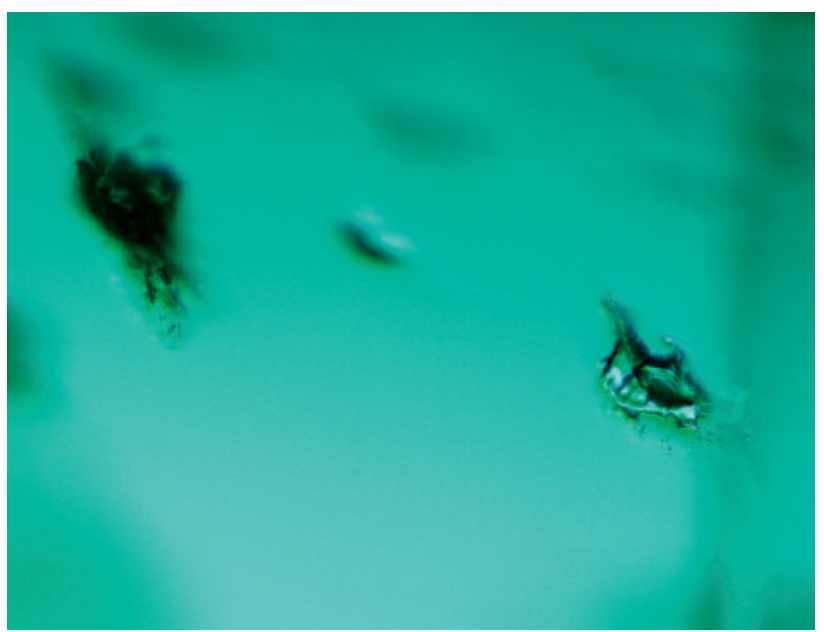


Figure 14. Slightly rounded grains of sodic plagioclase were identified in the emeralds. The crystal on the left is shown in transmitted light (image width $0.3 \mathrm{~mm}$ ), while the

larger one on the right is photographed in darkfield illumination (image width $1.4 \mathrm{~mm})$. Photomicrographs by J. C. Zwaan.
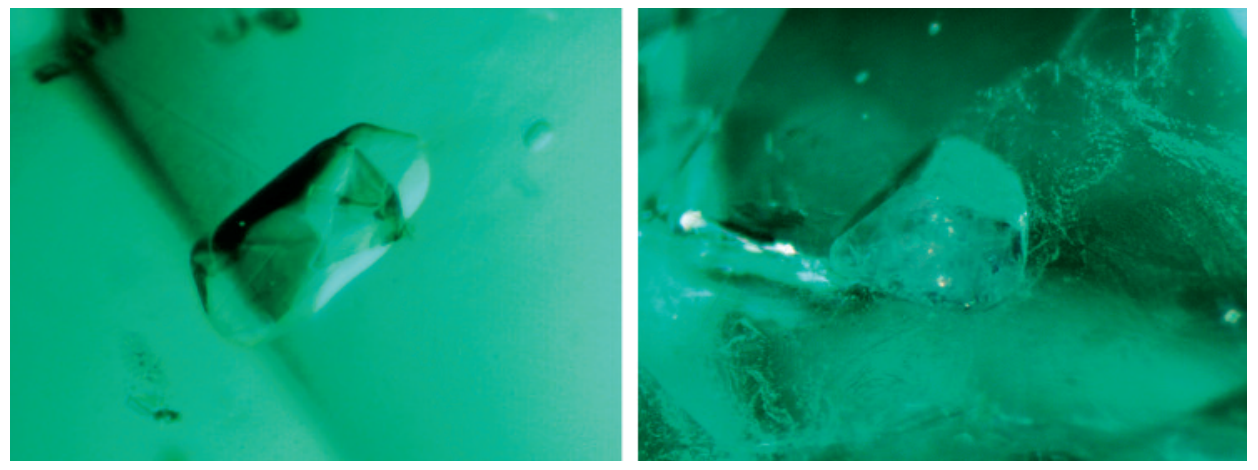

Figure 15. Platelets of phlogopite (left, image width 0.7 $\mathrm{mm}$ ) and clusters of minute inclusions of quartz (right, image width $1.5 \mathrm{~mm}$ ) were observed in some of the emeralds. Photomicrographs by J. C. Zwaan.
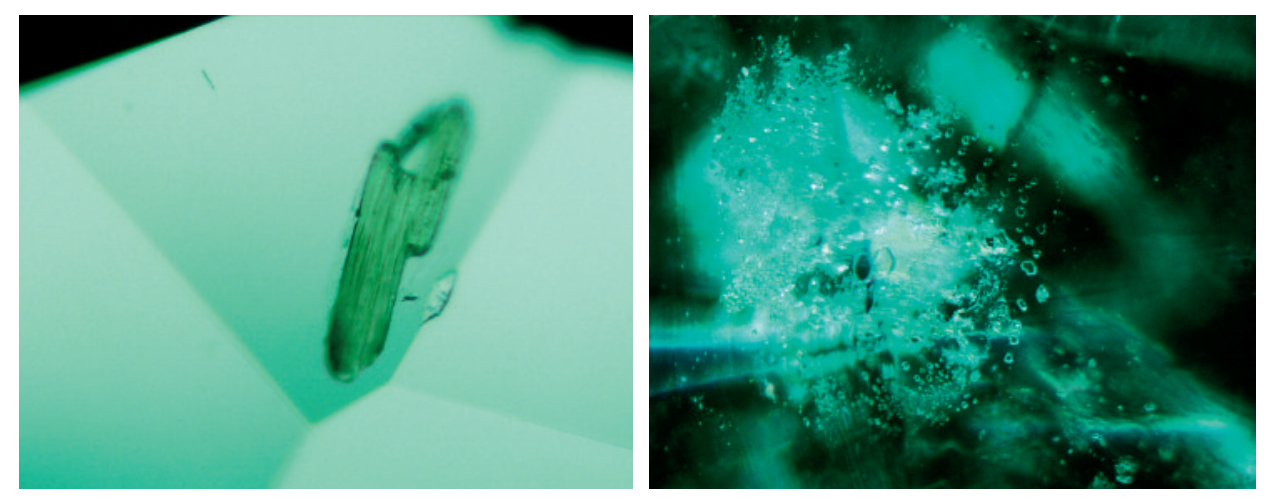

\section{CHEMICAL COMPOSITION}

Table 2 presents chemical analyses for representative samples of Fazenda Bonfim emeralds. A complete listing of all analyses, including ions calculated for the microprobe data, is available in the $G \uplus G$ Data Depository at gia.edu/gandg. The most important chromophore in the emeralds was $\mathrm{Cr}$, which averaged $0.32 \mathrm{wt} . \% \mathrm{Cr}_{2} \mathrm{O}_{3}$ and ranged from $0.16 \mathrm{wt} . \%$ in light bluish green samples to $0.72 \mathrm{wt} . \%$ in a medium bluish green stone. Vanadium concentrations were consistently low, averaging 0.03 wt.\% $\mathrm{V}_{2} \mathrm{O}_{3}$. The other chromophore was $\mathrm{Fe}$, which averaged $0.82 \mathrm{wt} . \% \mathrm{FeO}$ and showed a maximum of 1.04 wt. \% FeO.

The emeralds contained relatively high concentrations of $\mathrm{Mg}$ (average $2.27 \mathrm{wt} . \% \mathrm{MgO}$ ) but rather low
$\mathrm{Na}$ (average 0.66 wt. \% $\mathrm{Na}_{2} \mathrm{O}$ ). Traces of $\mathrm{Ca}, \mathrm{K}, \mathrm{Cs}, \mathrm{Li}$, $\mathrm{P}, \mathrm{Sc}, \mathrm{Ti}, \mathrm{Mn}, \mathrm{Co}, \mathrm{Ni}, \mathrm{Zn}, \mathrm{Ga}$, and $\mathrm{Rb}$ were detected in all of the samples. Potassium values were consistently high (average of $764 \mathrm{ppm}$ ), whereas Li contents were rather low (average of $106 \mathrm{ppm}$ ).

Table 3 summarizes the trace-element ranges obtained from LA-ICP-MS data for emeralds from Fazenda Bonfim, Kafubu, and Sandawana (see Discussion for comparison).

\section{SPECTROSCOPY}

The UV-Vis-NIR spectra were typical for emeralds with considerable iron content. The ordinary ray $(\mathrm{E} \perp \mathrm{c}$; figure 18) showed broad bands at approximately 438 and 605 $\mathrm{nm}$, a weaker peak at $478 \mathrm{~nm}$, and a doublet at 680 and

Figure 16. This fluid inclusion in an emerald contains doubly refractive captured minerals, mainly carbonate and mica along with bertran-

dite in the carbonate. Photomicrographs by J. C. Zwaan, transmitted light (left) and between crossed polarizers (right); image width $\sim 0.3 \mathrm{~mm}$.
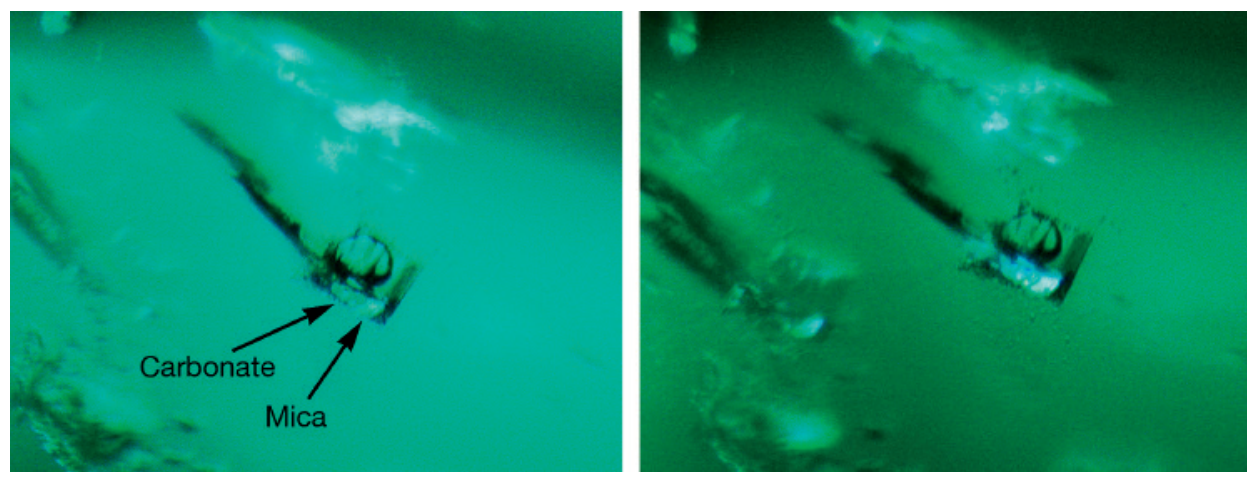
TABLE 2. Average chemical composition of representative emeralds from Fazenda Bonfim. ${ }^{a}$

\begin{tabular}{|c|c|c|c|c|c|c|c|c|c|c|c|c|c|c|c|}
\hline Sample & N1 & \multirow{3}{*}{$\begin{array}{c}\mathrm{N} 2 \\
1.92 \\
\text { Med. } \\
\mathrm{bG}\end{array}$} & \multirow{3}{*}{$\begin{array}{c}\text { N3 } \\
1.29 \\
\text { Med. } \\
\text { bG }\end{array}$} & \multirow{3}{*}{$\begin{array}{c}\text { N4 } \\
1.26 \\
\text { Med.-It. } \\
\text { bG }\end{array}$} & \multirow{3}{*}{$\begin{array}{c}\text { N5 } \\
0.15 \\
\text { Int. It. } \\
\text { sl. bG }\end{array}$} & \multirow{3}{*}{$\begin{array}{c}\text { N6 } \\
0.18 \\
\text { Med. } \\
\text { bG }\end{array}$} & \multirow{3}{*}{$\begin{array}{c}\text { N7 } \\
0.19 \\
\text { Med.-It. I } \\
\text { bG }\end{array}$} & \multirow{3}{*}{$\begin{array}{c}\text { N8 } \\
0.20 \\
\text { Med.-It. } \\
\text { bG }\end{array}$} & \multirow{3}{*}{$\begin{array}{c}\text { N9 } \\
0.23 \\
\text { Med. } \\
\text { v.st. bG }\end{array}$} & \multirow{3}{*}{$\begin{array}{c}\text { N10 } \\
0.19 \\
\text { Med-lt. } \\
\text { bG }\end{array}$} & \multirow{3}{*}{$\begin{array}{c}\text { N11 } \\
0.19 \\
\text { Med.-It. } \\
\text { bG }\end{array}$} & \multirow{3}{*}{$\begin{array}{c}\text { N12 } \\
0.19 \\
\text { Med.-It. } \\
\text { bG }\end{array}$} & \multirow{3}{*}{$\begin{array}{c}\text { N13 } \\
0.21 \\
\text { Med.-It. } \\
\text { bG }\end{array}$} & \multirow{3}{*}{$\begin{array}{c}\text { N14 } \\
0.19 \\
\text { Med.-It. } \\
\text { bG }\end{array}$} & \multirow{3}{*}{$\begin{array}{c}\text { N15 } \\
0.17 \\
\text { Lt. bG }\end{array}$} \\
\hline \multicolumn{2}{|c|}{$\begin{array}{l}\text { Sample } \quad \mathrm{N1} \\
\text { Weight (ct) } 3.89\end{array}$} & & & & & & & & & & & & & & \\
\hline Color N & $\begin{array}{l}\text { Med-dk. } \\
\text { bG }\end{array}$ & & & & & & & & & & & & & & \\
\hline \multicolumn{16}{|c|}{ Oxides (wt.\%) } \\
\hline $\mathrm{SiO}_{2}$ & 63.30 & 63.51 & 63.03 & 63.23 & 63.20 & 63.39 & 63.56 & 63.33 & 63.15 & 63.71 & 62.85 & 63.37 & 63.79 & 63.70 & 62.98 \\
\hline $\mathrm{l}_{2} \mathrm{O}_{3}^{2}$ & 14.49 & 14.41 & 14.41 & 14.30 & 13.90 & 14.52 & 13.80 & 14.48 & 14.48 & 14.62 & 13.82 & 14.69 & 14.58 & 14.76 & 14.02 \\
\hline $\mathrm{Sc}_{2} \mathrm{O}_{3}$ & bdl & 0.02 & bdl & bdl & 0.02 & bdl & 0.03 & bdl & bdl & 0.03 & $3 \quad 0.02$ & bdl & bdl & bdl & 0.02 \\
\hline & 0.03 & 0.02 & 0.04 & 0.03 & 0.03 & 0.03 & 0.03 & 0.02 & 0.03 & 0.03 & 0.03 & 0.03 & 0.03 & 0.04 & 0.03 \\
\hline $\mathrm{Cr}_{2} \mathrm{O}_{3}$ & 0.32 & 0.25 & 0.18 & 0.23 & 0.42 & 0.57 & 0.35 & 0.31 & 0.49 & 0.44 & 0.36 & 0.29 & 0.20 & 0.25 & 0.16 \\
\hline $\mathrm{BeO}(\mathrm{calc})$ & c) 13.08 & 13.09 & 13.07 & 13.05 & 13.04 & 13.10 & 13.09 & 13.07 & 13.04 & 13.14 & 12.99 & 13.13 & 13.12 & 13.15 & 13.00 \\
\hline $\mathrm{FeO}$ & 0.82 & 0.76 & 0.90 & 0.75 & 0.87 & 0.75 & & 0.66 & 1.01 & 0.71 & 0.97 & 0.74 & 0.48 & 0.74 & 0.94 \\
\hline $\mathrm{MgO}$ & 2.22 & 2.23 & 2.37 & 2.24 & 2.53 & 2.07 & 2.54 & 2.24 & 1.72 & 2.13 & 2.51 & 2.2 & 2.25 & 2.25 & 2.49 \\
\hline $\mathrm{CaO}$ & 0.04 & 0.05 & 0.05 & 0.04 & 0.06 & 0.03 & 0.07 & 0.04 & 0.03 & 0.03 & 0.0 & 0.0 & 0.04 & 0.04 & 0.07 \\
\hline $\mathrm{Na}_{2} \mathrm{O}$ & 0.59 & 0.62 & 0.91 & 0.81 & 0.68 & 0.64 & 0.81 & 0.52 & 0.79 & 0.52 & 0.68 & 0.81 & 0.38 & 0.43 & 0.56 \\
\hline $\mathrm{K}_{2} \mathrm{O}$ & 0.05 & 0.06 & 0.07 & 0.06 & 0.06 & 0.07 & 0.08 & 0.04 & 0.03 & 0.04 & 0.07 & 0.06 & 0.04 & 0.05 & 0.07 \\
\hline $\mathrm{Rb}_{2} \mathrm{O}$ & bdl & bdl & bdl & bdl & bdl & bdl & bdl & & Dal & bdl & & & bdl & bdl & \\
\hline $\mathrm{Cs}_{2} \mathrm{O}$ & 0.02 & bdl & 0.04 & 0.03 & 0.04 & 0.05 & 0.04 & 0.05 & 0.03 & 0.04 & 0.04 & 0.02 & 0.02 & bdl & 0.04 \\
\hline
\end{tabular}

Minor and trace elements $(\mathrm{ppm})^{\mathrm{d}}$

\begin{tabular}{|c|c|c|c|c|c|c|c|c|c|c|c|c|c|c|c|}
\hline $\mathrm{Li}$ & 128 & 99 & 116 & 113 & 104 & 108 & 105 & 84 & 88 & 107 & 122 & 74 & 108 & 82 & 109 \\
\hline B & 1.1 & bdl & bdl & $\mathrm{bd}$ & dl 1.3 & bdl & bdl & bdl & bdl & 1.0 & bdl & bdl & bdl & 2.0 & 1.4 \\
\hline D & 89 & 90 & 85 & 94 & 88 & 96 & 95 & 99 & 96 & 104 & 98 & 97 & 94 & 112 & 87 \\
\hline K & 792 & 903 & 1212 & 1024 & 922 & 902 & 1098 & 626 & 496 & 626 & 1245 & 665 & 777 & 724 & 1088 \\
\hline $\mathrm{Ca}$ & 416 & 444 & 734 & 418 & 479 & 250 & 543 & 385 & 194 & 227 & 620 & 377 & 344 & 439 & 497 \\
\hline Sc & 96 & 72 & 138 & 66 & 104 & 53 & 101 & 45 & 122 & 145 & 169 & 81 & 45 & 91 & 114 \\
\hline 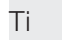 & 6.9 & 4.4 & 7.0 & 4.9 & 3.3 & 7.0 & 4.1 & 4.2 & 3.2 & 3.2 & 7.0 & 3.9 & 3.3 & 5.6 & 7.0 \\
\hline 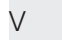 & 123 & 121 & 146 & 116 & 136 & 175 & 139 & 90 & 171 & 140 & 150 & 114 & 97 & 117 & 144 \\
\hline $\mathrm{Cr}$ & 2164 & 1637 & 1409 & 2006 & 2744 & 4222 & 2525 & 1504 & 2916 & 2995 & 2365 & 1946 & 1547 & 1768 & 1748 \\
\hline $\mathrm{Mn}$ & 9.6 & 11 & 15 & 12 & 11 & 15 & 12 & 9.6 & 19 & 12 & 14 & 9.2 & 10 & 11 & 14 \\
\hline Co & 2.5 & 2.2 & 2.4 & 2.4 & 2.3 & 2.2 & 2.4 & 2.2 & 2.1 & 2.0 & 2.4 & 2.2 & 2.1 & 2.3 & 2.6 \\
\hline & 16 & 15 & 15 & 16 & 16 & 21 & 16 & 15 & 19 & 18 & 16 & 15 & 15 & 16 & 16 \\
\hline $\mathrm{Su}$ & bdl & bdl & bdl & bdl & bdl & bdl & bdl & bdl & bdl & bdl & 0.54 & 0.61 & 0.79 & 29 & \\
\hline $7 \mathrm{n}$ & 25 & 20 & 17 & 20 & 18 & 44 & 19 & 19 & 78 & 44 & 20 & 17 & 18 & 49 & 20 \\
\hline Ga & 20 & 19 & 19 & 18 & 19 & 17 & 21 & 18 & 47 & 31 & 22 & 18 & 19 & 17 & 20 \\
\hline $\mathrm{Ge}$ & bdl & bdl & bdl & bdl & bdl & 0.83 & bdl & bdl & 0.72 & 0.76 & bdl & bdl & bdl & bdl & bdl \\
\hline $\mathrm{Rb}$ & 67 & 69 & 80 & 68 & 82 & 65 & 81 & 62 & 52 & 60 & 85 & 66 & 67 & 66 & 83 \\
\hline $\mathrm{Sr}$ & 0.06 & 0.05 & 0.10 & 0.06 & 0.04 & bdl & 0.07 & 0.04 & bdl & bdl & 0.15 & 0.03 & 0.06 & 0.78 & 0.05 \\
\hline & 0.05 & 0.05 & 0.07 & bdl & 0.06 & 0.04 & 0.06 & 0.03 & bdl & 0.04 & 0.09 & bdl & 0.05 & 0.06 & 0.06 \\
\hline$Z r$ & 0.10 & 0.07 & 0.13 & 0.10 & 0.11 & bdl & 0.10 & 0.09 & bdl & bdl & 0.23 & 0.09 & 0.09 & 0.13 & bdl \\
\hline $\mathrm{Nb}$ & bdl & bdl & bdl & bdl & bdl & bdl & bdl & bdl & bdl & 0.03 & bdl & bdl & bdl & 0.17 & bdl \\
\hline 4 & bc & bdl & bdl & bdl & bdl & bdl & bdl & bdl & bdl & bdl & bdl & bdl & bdl & bdl & bdl \\
\hline n & bdl & l bdl & 1.1 & bdl & 0.77 & bdl & bdl & bdl & 0.79 & bdl & \| $\quad 1.3$ & bdl & bdl & 2.1 & 1.1 \\
\hline Cs & 273 & 252 & 375 & 241 & 311 & 494 & 303 & 222 & 340 & 408 & 380 & 233 & 217 & 238 & 392 \\
\hline $\mathrm{Ba}$ & bdl & l bdl & bdl & bdl & 0.22 & bdl & bdl & bdl & 0.26 & bdl & $\| \quad b d l$ & bdl & bdl & 1.2 & bdl \\
\hline $\mathrm{La}$ & bdl & bdl & 0.02 & bdl & bdl & bdl & bdl & bdl & 0.03 & bdl & bdl & bdl & bdl & 0.04 & bdl \\
\hline Ta & 0.06 & 0.06 & 0.08 & 0.05 & 0.06 & bdl & 0.06 & 0.06 & bdl & bdl & 0.07 & 0.05 & bdl & 0.05 & 0.11 \\
\hline $\mathrm{Au}$ & bdl & bdl & bdl & bdl & bdl & bdl & bdl & bdl & bdl & bdl & bdl & bdl & bdl & bdl & bdl \\
\hline $\mathrm{Pb}$ & bdl & bdl & bdl & bdl & 0.07 & bdl & bdl & bdl & bdl & bdl & 0.12 & bdl & bdl & 1.7 & 0.11 \\
\hline $\mathrm{Bi}$ & bdl & bdl & bdl & bdl & 0.06 & bdl & 0.04 & bdl & bdl & bdl & 0.07 & bdl & bdl & 0.04 & 0.07 \\
\hline
\end{tabular}

a Abbreviations: $b d l=$ below detection limit; $b G=$ bluish green, lt. = light, med. $=$ medium, $d k .=$ dark, Int. = intense, sl. = slightly, v.st. = very strongly.

${ }^{b}$ Oxides analyzed by electron microprobe; average of three analyses per sample on different spots (four analyses of sample N3). For complete electron

microprobe analyses, including the calculated ions per formula unit, see the G\&G Data Depository.

c $\mathrm{BeO}$ was calculated based on an assumed stoichiometry of 3 Be atoms per formula unit.

${ }^{d}$ Trace elements analyzed by LA-ICP-MS; average of three analyses per sample on different spots (two analyses of sample N7).

$683 \mathrm{~nm}$, all indicating the presence of $\mathrm{Cr}^{3+}$. A band at about $835 \mathrm{~nm}$ pointed to the presence of $\mathrm{Fe}^{2+}$, whereas the peak at about $371 \mathrm{~nm}$ demonstrated $\mathrm{Fe}^{3+}$ (compare Wood and Nassau, 1968; Schmetzer et al., 1974;
Platonov et al., 1978).

FTIR measurements yielded spectra consistent with alkali-bearing emeralds (figure 19). A peak at around $7095 \mathrm{~cm}^{-1}$ indicated the presence of type II water (i.e., 
Figure 17. The doubly re-

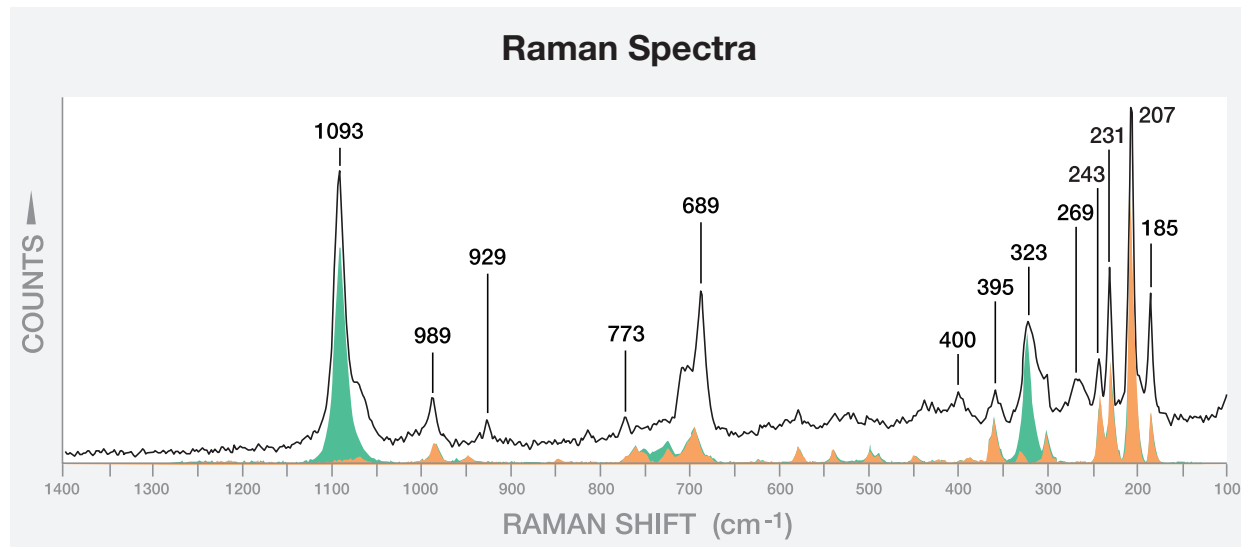

water molecules associated with alkali ions in the channels of the beryl structure; Wood and Nassau, 1968). The alkali ions in these emeralds were mainly $\mathrm{Na}^{+}, \mathrm{K}^{+}$, $\mathrm{Cs}^{+}$, and $\mathrm{Li}^{+}$. As non-polarized spectra were obtained from faceted and cabochon-cut specimens, the $5272 \mathrm{~cm}^{-1}$ peak could not be confirmed as a type II water absorption band; this can only be proven when a polarized spectrum is taken perpendicular to the c-axis (Schmetzer et al., 1997). A smaller peak at $3234 \mathrm{~cm}^{-1}$ was related to either type $\mathrm{II} \mathrm{H}_{2} \mathrm{O}$ or to $(\mathrm{OH})^{-}$oriented parallel to the c-axis (Banko, 1995, 1997). The broad band between about 3900 and $3400 \mathrm{~cm}^{-1}$ was due to type II and type I water molecules (type I are not linked to other ions).

The FTIR spectra consistently showed a strong band

Figure 18. A representative absorption spectrum of an emerald from Fazenda Bonfim, in the direction of the ordinary ray $(E \perp c)$, shows the presence of $\mathrm{Cr}^{3+}, \mathrm{Fe}^{2+}$, and $\mathrm{Fe}^{3+}$. The approximate path length of the beam is $5 \mathrm{~mm}$.

\section{UV-Vis-NIR Spectrum}

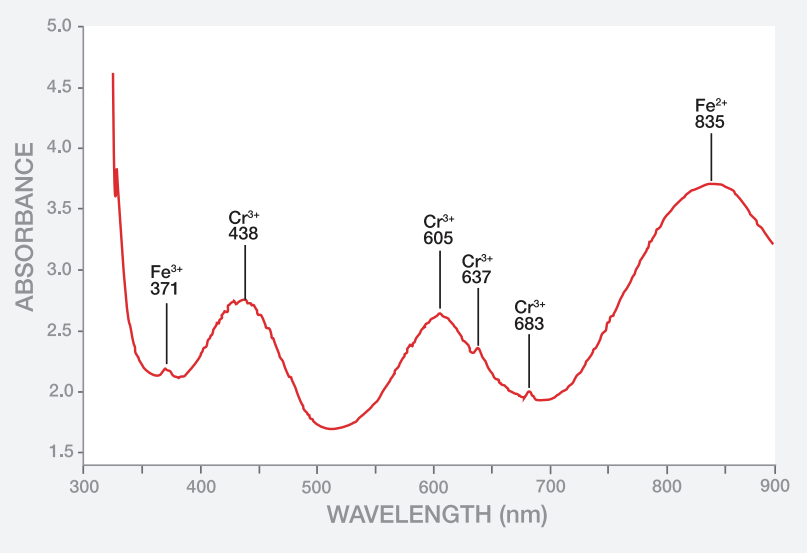

at $2357 \mathrm{~cm}^{-1}$, indicating the presence of $\mathrm{CO}_{2}$. This band is strongly dichroic, with greater absorption for the ordinary ray, a feature related to the orientation of $\mathrm{CO}_{2}$ within the channel of the beryl structure (Wood and Nassau, 1968). Very weak peaks at 2671 and $2640 \mathrm{~cm}^{-1}$ can be assigned to type I and type II HOD molecules (de Donato et al., 2004), indicating the presence of deuterium next to hydrogen in some of the water molecules ("deuterated water").

None of our spectra indicated a resin in any of the samples, nor did we see any green fillers. Stones with fractures containing a near-colorless filler showed a higher peak around $2925 \mathrm{~cm}^{-1}$, as well as lower peaks around 2854 and $2955 \mathrm{~cm}^{-1}$ that are typical for an oil (e.g., Johnson et al., 1999; Kiefert et al., 1999).

\section{DISCUSSION}

Physical Properties. The relatively high refractive indices of Fazenda Bonfim emeralds are typical for emeralds from schist- and pegmatite-related deposits. These high RIs are caused by the presence of alkali ions, water, and substantial $\mathrm{Mg}$ and Fe (Wood and Nassau, 1968; Černý and Hawthorne, 1976). Zwaan et al. (2005) compared other commercially available emeralds with similar RI, birefringence, and SG values. Based on that comparison, the distinguishing internal features of Fazenda Bonfim emeralds (prominent fluid inclusions, parallel growth tubes, and few solid inclusions) differ considerably. Although many of their internal features are comparable to those encountered in emeralds from the Itabira District of Minas Gerais (compare Hänni et al., 1987; Souza, 1988; Souza et al., 1992; Zwaan, 2001; and Rondeau et al., 2003), the absence of amphibole in the Fazenda Bonfim emeralds is distinctive. Amphibole inclusions are common in emeralds from many other 


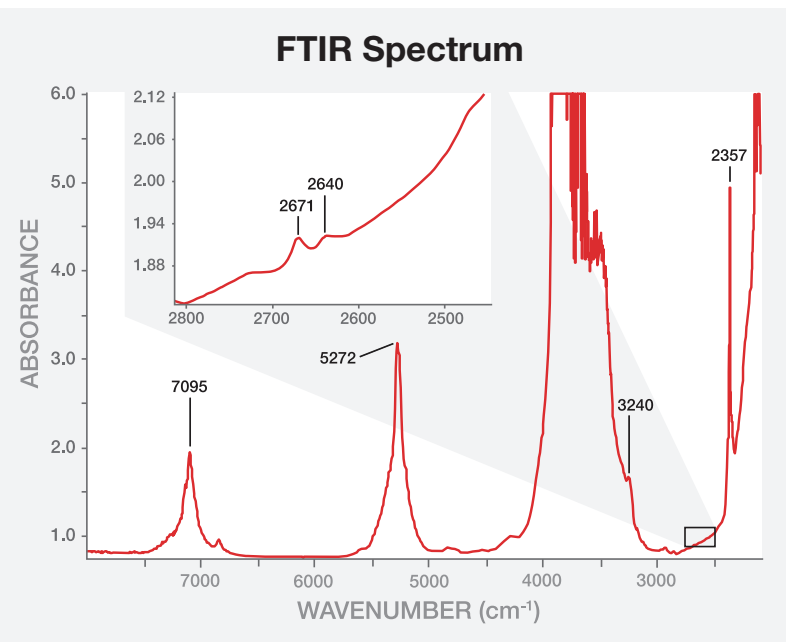

Figure 19. This representative mid-FTIR spectrum of a Fazenda Bonfim emerald shows a $7095 \mathrm{~cm}^{-1}$ peak caused by vibrations of water molecules adjacent to alkali ions in the channel sites. Those same water molecules and unassociated water molecules caused the broad band between 3900 and $3400 \mathrm{~cm}^{-1}$. The peak at $2357 \mathrm{~cm}^{-1}$, due to $\mathrm{CO}_{2}$, was consistently high in the samples. The inset shows very weak peaks at 2671 and $2640 \mathrm{~cm}^{-1}$ that indicate the presence of deuterated water. The approximate path length of the beam is $5 \mathrm{~mm}$.

schist-related emerald deposits (e.g., Schwarz, 1998; Zwaan et al., 2005).

Chemical Properties. Using Schwarz's (1990a) empirical subdivision of low, medium, and high concentrations of elements in emerald, the Fazenda Bonfim stones show low $\mathrm{Na}$ and $\mathrm{V}$, and moderate $\mathrm{Cr}, \mathrm{Fe}$, and $\mathrm{Mg}$. Notable are the relatively high $\mathrm{K}$ and low Li contents compared to most emeralds from Zambia and Zimbabwe, which also come from schist-type deposits related to pegmatitic intrusions (table 3 and figure 20). Only some Zambian emeralds show very high $\mathrm{K}$ values combined with lower Li. A better separation between the three localities can be made by plotting Ga versus Li (figure 21). The Fazenda Bonfim emeralds have low Li values and moderate-to-high Ga.

A clear separation between the three localities can also be made by plotting data for $\mathrm{K}, \mathrm{Li}+\mathrm{Cs}$, and $\mathrm{Rb}$ in a ternary diagram (figure 22). The Fazenda Bonfim emeralds show intermediate $\mathrm{K}$ and $\mathrm{Li}+\mathrm{Cs}$ contents, and stand out clearly from Sandawana emeralds and most Zambian emeralds that show high $\mathrm{Li}+\mathrm{Cs}$, and from some Zambian stones that are K-dominant. The Zim-
TABLE 3. Trace-element concentrations (ppm) of emeralds from three pegmatite-related deposits. ${ }^{a}$

Deposit \begin{tabular}{c}
$\begin{array}{c}\text { Fazenda Bonfim, } \\
\text { Brazil }\end{array}$ \\
\cline { 2 - 2 } Samples
\end{tabular}

Trace element (ppm)

$\begin{array}{cccc} & (106) & (514) & (492) \\ \text { B } & \text { bdl-3.4 } & \text { bdl-10.7 } & \text { bdl-1.6 } \\ \text { P } & 70-132 & 92-167 & 76-128\end{array}$

$\begin{array}{cccc} & (96) & (118) & (109) \\ \mathrm{K} & 398-1306 & 30-2728 & 134-431\end{array}$

\begin{tabular}{|c|c|c|c|}
\hline & (764) & $(671)$ & (263) \\
\hline $\mathrm{Ca}$ & 161-966 & $65-782$ & $46-72$ \\
\hline
\end{tabular}

(360) (314) (131)

Sc 22-170 2.7-349 13-109

$\begin{array}{cccc} & (89) & (108) & (43) \\ \mathrm{Ti} & 1.8-8.7 & 1.8-25 & 2.5-179\end{array}$

(4.8) (8.5)

$\begin{array}{cccc}\text { V } & 60-180 & 34-333 & 101-379 \\ & (128) & (108) & (257) \\ \text { Cr } & 887-4976 & 374-4507 & 1363-7821\end{array}$

$1363-7821$

(2277) (1835) (4752)

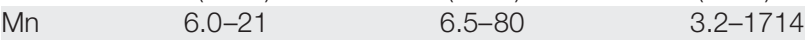

$\begin{array}{cccc} & (11.4) & (27) & (66) \\ \text { Co } & 1.5-2.7 & 0.99-5.9 & 1.6-7.6\end{array}$

(2.1) (3.0) (2.5)

\begin{tabular}{|c|c|c|c|}
\hline $\mathrm{Ni}$ & $\begin{array}{c}8.8-22 \\
(15)\end{array}$ & $\begin{array}{c}9.8-50 \\
(19)\end{array}$ & $\begin{array}{c}9.9-84 \\
(19)\end{array}$ \\
\hline $\mathrm{Cu}$ & bdl-29 & bdl-0.57 & bdl-4.4 \\
\hline $\mathrm{Zn}$ & $\begin{array}{c}14-110 \\
(26)\end{array}$ & $\begin{array}{c}12.7-129 \\
(39)\end{array}$ & $\begin{array}{c}30-294 \\
(82)\end{array}$ \\
\hline $\mathrm{Ga}$ & $\begin{array}{c}14-49 \\
(20)\end{array}$ & $\begin{array}{c}6.8-18 \\
(12)\end{array}$ & $\begin{array}{c}19-44 \\
(28)\end{array}$ \\
\hline $\mathrm{Ge}$ & bdl-1.0 & bdl-1.6 & bdl-0.84 \\
\hline $\mathrm{Rb}$ & $\begin{array}{c}52-101 \\
(72)\end{array}$ & $\begin{array}{c}12.4-223 \\
(76)\end{array}$ & $\begin{array}{c}120-328 \\
(222)\end{array}$ \\
\hline $\mathrm{Sr}$ & bdl-0.78 & bdl-0.21 & bdl-0.23 \\
\hline Y & bdl-0.13 & bdl-0.06 & bdl-0.14 \\
\hline $\mathrm{Zr}$ & bdl-0.33 & bdl-0.19 & bdl-3.0 \\
\hline $\mathrm{Nb}$ & bdl-0.17 & bdl-0.06 & bdl-0.65 \\
\hline Mo & bdl & bdl-0.21 & bdl-0.26 \\
\hline Sn & bdl-2.1 & bdl-14.8 & bdl-14.1 \\
\hline Cs & $\begin{array}{c}213-557 \\
(345)\end{array}$ & $\begin{array}{c}131-1927 \\
(739)\end{array}$ & $\begin{array}{c}251-1315 \\
(654)\end{array}$ \\
\hline $\mathrm{Ba}$ & bdl-1.2 & bdl-6.9 & bdl-0.5 \\
\hline $\mathrm{La}$ & bdl-0.06 & bdl-0.04 & bdl-0.16 \\
\hline Ta & bdl-0.57 & bdl-0.06 & bdl-0.74 \\
\hline $\mathrm{Au}$ & bdl-0.12 & bdl & bdl \\
\hline $\mathrm{Pb}$ & bdl-1.7 & bdl-4.5 & bdl-5.7 \\
\hline $\mathrm{Bi}$ & bdl-0.12 & bdl-0.06 & bdl-0.07 \\
\hline
\end{tabular}

a Element ranges are shown, with average values in parentheses. Abbreviation: bdl = below detection limit.

babwean emeralds can be distinguished from Zambian material by their higher $\mathrm{Rb}$ content. When a beryl is Li-rich, Cs typically appears in higher concentrations as well (Bakakin and Belov, 1962). Generally speaking, extremely fractionated rare-element granitic pegmatites 


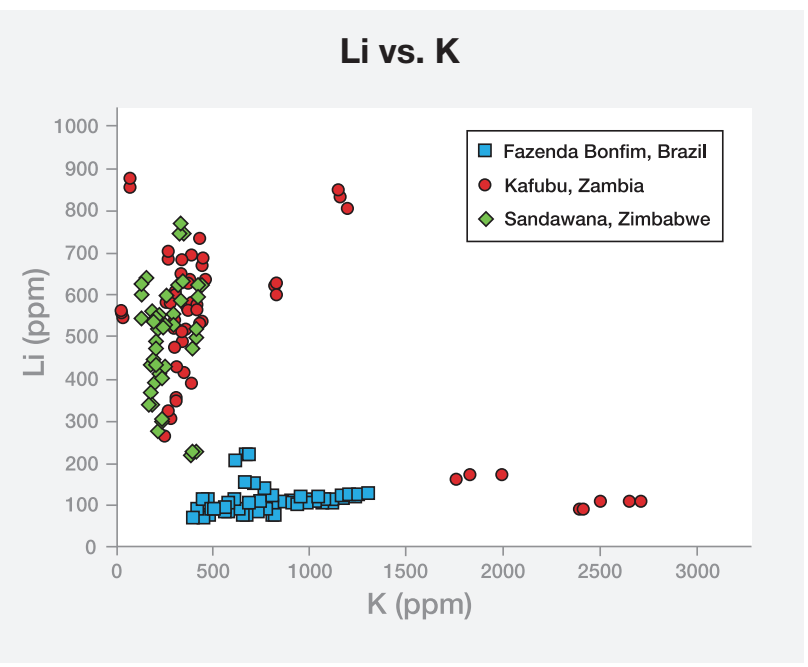

Figure 20. This plot shows the relatively high $\mathrm{K}$ and low Li concentrations in Fazenda Bonfim emeralds compared to those in Sandawana (Zimbabwe) and Kafubu (Zambia) samples.

of the LCT association (lithium, cesium, tantalum) are enriched in Li and Cs (e.g., Černý et al., 1985; Simmons, 2007). Emeralds from Zambia and Zimbabwe are found in close connection to highly evolved pegmatites (e.g., Seifert et al., 2004; Zwaan, 2006) and indeed show high $\mathrm{Li}$ and Cs. In Rio Grande do Norte, the pegmatites of the Borborema Pegmatitic Province are not considered among the most evolved, and they are classified under

Figure 21. A plot of Li versus Ga separates Fazenda Bonfim emeralds, which have low Li values and moderate-to-high Ga, from Zambian stones (lower Ga with higher Li) and Zimbabwean emeralds (higher Li and $G a$ ).

\section{Li vs. Ga}

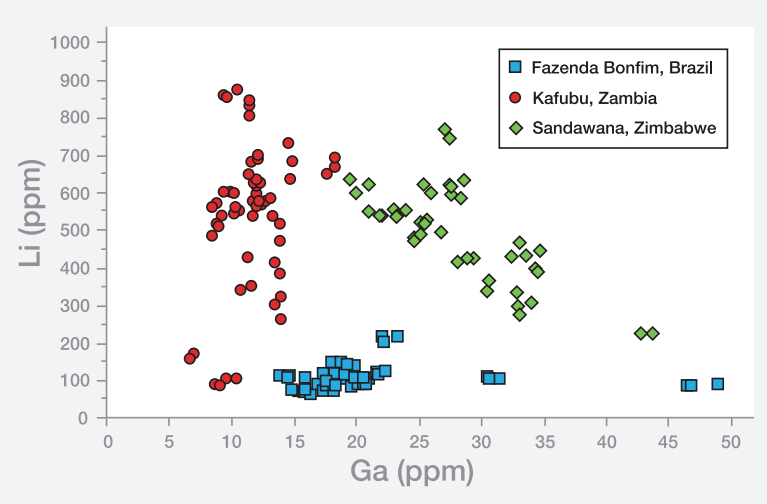

\section{Ternary Plot}

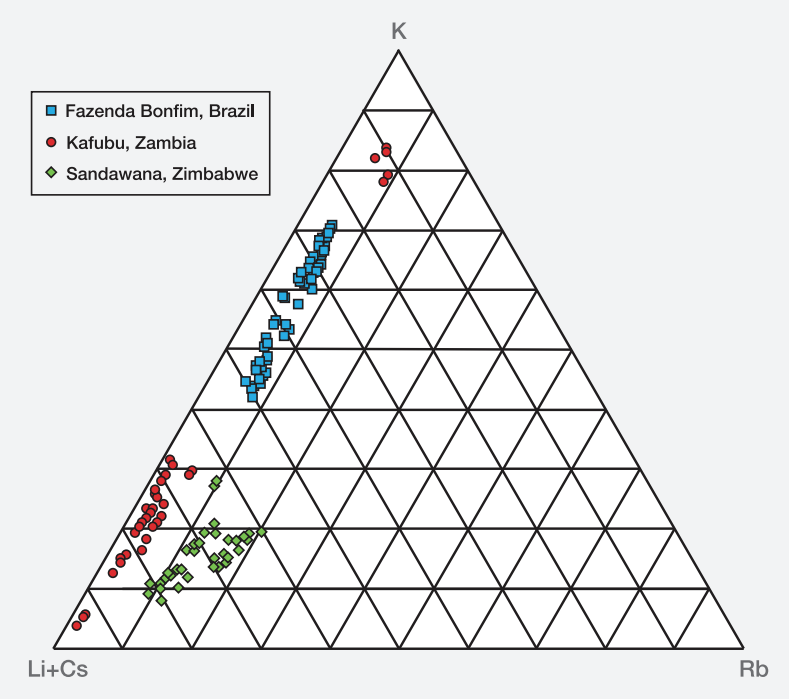

Figure 22. The concentrations of $K, L i+C s$, and $R b$ in emeralds from Fazenda Bonfim, Zambia, and Zimbabwe are plotted in this ternary diagram. The Fazenda Bonfim emeralds show intermediate $K$ and $\mathrm{Li}+\mathrm{Cs}$ content and are clearly distinguished from Zimbabwean emeralds and most Zambian emeralds that show enriched Li+Cs. The Zimbabwean emeralds have relatively higher $R b$.

Černý's (1989) "beryl-columbite-phosphate" subtype (Da Silva et al., 1995). This is consistent with the lower $\mathrm{Li}$ and $\mathrm{Cs}$ in the associated emeralds from Fazenda Bonfim.

Compared to our LA-ICP-MS results (table 3), analyses of emeralds from Kafubu and Sandawana by Abduriyim and Kitawaki (2006) show similar trends for most elements, although they reported higher Li values for Zambian emeralds (320-1260 ppm). They also gave higher upper limits for Li in Sandawana emeralds (1370 ppm), as well as very high Cs in those samples (up to $0.30 \mathrm{wt} . \% \mathrm{Cs}_{2} \mathrm{O}$ ). In Zambian emeralds, they reported higher upper limits for $Z n$ (up to $970 \mathrm{ppm}$ ) and for $\mathrm{Ga}$ (up to $55 \mathrm{ppm}$ ). Because average values were not listed by those authors, it is difficult to assess the significance of these differences in results. Zwaan et al. (2005) showed that in one emerald crystal from Zambia, cesium ranged from 0.05 to 0.23 wt. $\% \mathrm{Cs}_{2} \mathrm{O}$ (microprobe analyses), with the highest concentration in the outer portion of the crystal. So variations in traceelement concentration may depend highly on the precise locations chosen for spot analyses. 


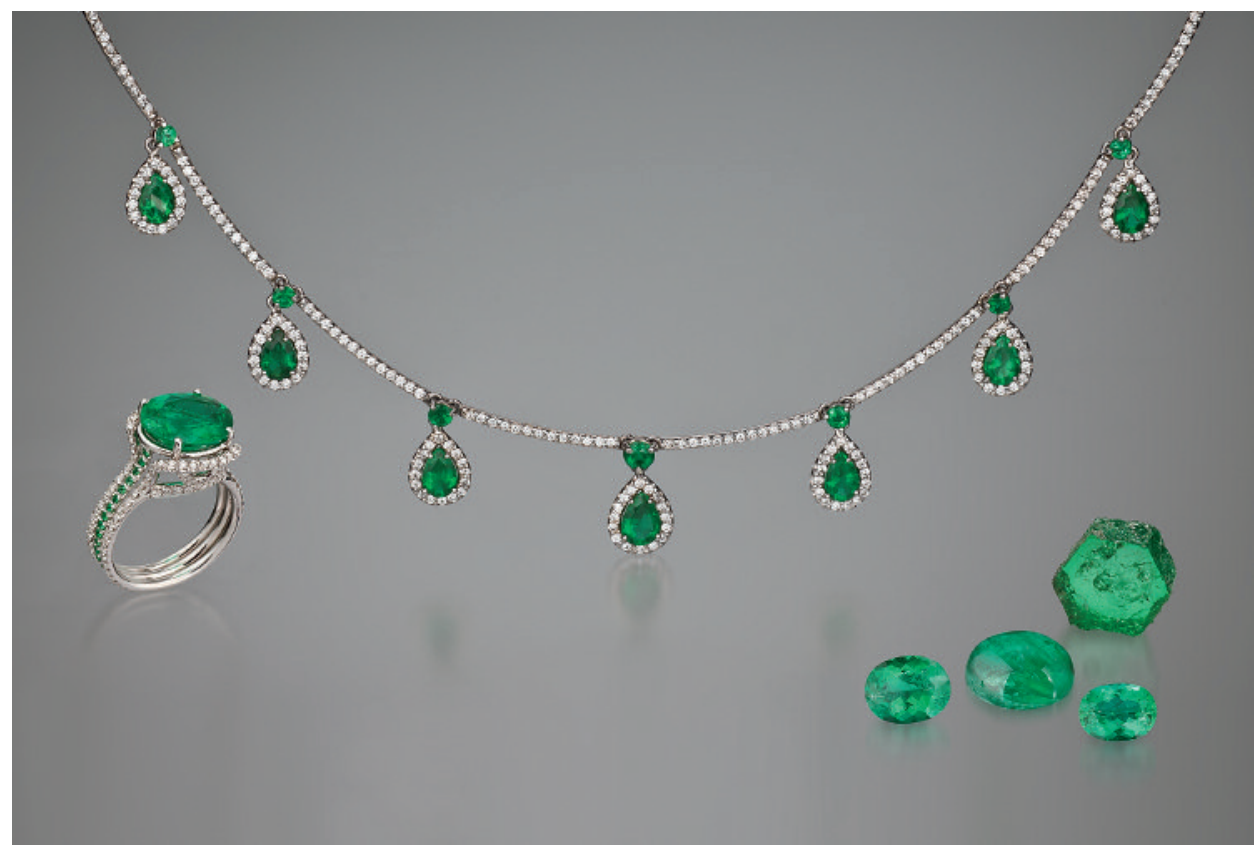

Figure 23. Emeralds from Fazenda Bonfim are somewhat similar to those from Itabira, Brazil. Shown here are loose Fazenda Bonfim emeralds - the faceted stones weigh 1.29 and 1.92 $c t$, the cabochon is $3.89 \mathrm{ct}$, and the crystal section (courtesy of Nature's Geometry, Laguna Beach, California) measures $5.5 \mathrm{~mm}$-along with jewelry featuring Brazilian emeralds. The ring contains a 3.20 ct Capoeirana emerald center stone and the necklace is set with Bahia emeralds; the pear shapes weigh 0.4 ct each. Jewelry courtesy of $A B C$ Gems Inc., Los Angeles; photo by Robert Weldon.

From chemical data reported in the literature, it can be deduced that emeralds from the Itabira District of Minas Gerais show overlapping values but generally higher $\mathrm{Na}_{2} \mathrm{O}$ content, up to $1.93 \mathrm{wt}$.\%. The average $\mathrm{Na}_{2} \mathrm{O}$ content reported for emeralds from the Belmont, Capoeirana, and Piteiras mines are 0.97, 0.99, and 1.52 wt.\%, respectively (Schwarz, 1990c; Zwaan, 2001). Rondeau et al. (2003) analyzed two representative samples from Piteiras and gave $\mathrm{Na}_{2} \mathrm{O}$ values of 1.43 and $1.58 \mathrm{wt}$. \%, respectively. LA-ICP-MS analyses also gave high $\mathrm{Na}_{2} \mathrm{O}$ contents, between 1.33 and 2.18 wt. \%, for Itabira emeralds (Abduriyim and Kitawaki, 2006). Additionally, emeralds from Itabira contain less Cs than those from Fazenda Bonfim; $\mathrm{Cs}_{2} \mathrm{O}$ was below the detection limit of the electron microprobe (Schwarz, 1990c; Zwaan, 2001) and up to only 0.01 wt. \% by LAICP-MS (Abduriyim and Kitawaki, 2006).

\section{CONCLUSION}

Emerald mineralization at Fazenda Bonfim occurs in association with ultramafic rocks in the Seridó Mobile Belt, within the Santa Monica Shear Zone. Small recrystallized pegmatitic bodies lie in a succession of talc, talc-amphibole, and biotite \pm amphibole schists, and emeralds occur in and around those bodies, particularly in the adjacent biotite schist near the contact with granitic gneiss.

The polished emeralds studied for this report typically displayed a saturated bluish green color with a medium-light to medium tone, and were very slightly to heavily included. Their relatively high refractive indices are typical for emeralds from schist-related deposits. The most commonly encountered inclusions were partially healed fissures with two-phase fluid inclusions (typically square, rectangular or "commalike") and fine, parallel-oriented growth tubes. The emeralds' chemical composition is characterized by relatively high $\mathrm{K}_{\text {; }}$ moderate $\mathrm{Cr}, \mathrm{Fe}$, and $\mathrm{Mg}_{\text {; }}$ and low $\mathrm{Na}, \mathrm{V}$, and Li. FTIR spectra showed characteristics of alkali-bearing emeralds with considerable $\mathrm{CO}_{2}$, as well as the presence of deuterated water.

The Fazenda Bonfim emeralds can be distinguished from those of other commercially important schistand pegmatite-related localities by careful comparison of physical and chemical properties, as well as internal features. Their properties show the most overlap with emeralds from the Itabira District of Brazil (e.g., figure 23), but they can still be differentiated by their significantly higher Cs and generally lower $\mathrm{Na}$.

Future emerald production from Fazenda Bonfim will depend on the extent of mineralization along the shear zone, both laterally and down the contact. 


\section{ABOUT THE AUTHORS}

Dr. Zwaan (zwaanj@naturalis.nl) is head of the Netherlands Gemmological Laboratory and a researcher at Naturalis, the national museum of natural history in Leiden, the Netherlands. Drs. Jacob and Häger are researchers at the Johannes Gutenberg University's Institute for Geosciences in Mainz, Germany. Dr. Cavalcanti Neto is a geologist at the Federal Institute for Education, Science and Technology of Rio Grande do Norte in Natal, Brazil. Mr. Kanis is a consultant based in Veitsrodt, Germany.

\section{ACKNOWLEDGMENTS}

The authors thank Mineração Vale Verde Ltd. (Caiçara do Rio do Vento, Brazil) for providing valuable information on the exploration and mining operation, granting full access to the deposit, and supplying samples for examination. We are grateful to Mr. J. Amancio Nery for logistical support. Dirk van der Marel (Netherlands Gemmological Laboratory) is thanked for his general assistance. Facilities for electron microprobe analyses were provided by the Free University of Amsterdam and by NWO, the Netherlands Organisation for Scientific Research. LA-ICP-MS analyses were performed at the Johannes Gutenberg University's Institute for Geosciences.

\section{REFERENCES}

Abduriyim A., Kitawaki H. (2006) Applications of laser ablationinductively coupled plasma-mass spectrometry (LA-ICP-MS) to gemology. Ge G, Vol. 42, No. 2, pp. 98-118, http://dx.doi.org/ 10.5741/GEMS.42.2.98.

Angelim L.A.A., Medeiros V.C., Nesi J.R. (2006) Programa Geologia do Brasil-PGB. Projeto Geológico e Recursos Minerais do Estado do Rio Grande do Norte. Mapa Geológico do Estado do Rio Grande do Norte. Escala 1:500.000. CPRM/FAPERN, Recife.

Araúio M.N.C., Vasconcelos P.M., Alves da Silva F.C., Jardim de Sá E., Sá J.M. $(2005){ }^{40} \mathrm{Ar} /{ }^{39} \mathrm{Ar}$ geochronology of gold mineralization in Brasiliano strike-slip shear zone in the Borborema Province, NE Brazil. Journal of South American Earth Sciences, Vol. 19, pp. 445-460, http://dx.doi.org/10.1016/j.jsames.2005.06.009.

Bakakin V.V., Belov N.V. (1962) Crystal chemistry of beryl. Geokhimiya, Vol. 5, pp. 420-433.

Banko A.G. (1995) Wasser- und Alkaligehaltbestimmung von Beryllen anhand der FTIR-Spektroskopie. Mitteilungen der Österreichische Mineralogischen Gesellschaft, Vol. 140, pp. 39-45.

Banko A.G. (1997) FTIR-Spektroskopische Untersuchungen na Beryllen unterschiedlicher Herkunft, sowie die Geologische, Mineralogische und Gemmologische Charakterisierung der Diamanten des Espinhaço-Gebirges (Minas Gerais, Brasilien). Dissertation am Institut für Mineralogie und Kristallografie, Universität Wien.

Calligaro T., Dran J.-C., Poirot J-P., Querré G., Salomon J., Zwaan J.C. (2000) PIXE/PIGE characterisation of emeralds using an external micro-beam. Nuclear Instruments and Methods in Physics Research B, Vol. 161-163, pp. 769-774, http://dx.doi.org/10.1016/ S0168-583X(99)00974-X.

Cassedanne J.P., Sauer D.A. (1984) The Santa Terezinha de Goiás emerald deposit. GÆ)G, Vol. 20, No. 1, pp. 4-13, http://dx.doi.org/ 10.5741/GEMS.20.1.4.

Cavalcanti Neto M.T.O., Barbosa R.V.N. (2007) As esmeraldas de Lajes, Caiçara do Rio dos Ventos e São Tomé/RN. Holos, Ano 23, Vol. 2, pp. 92-104.

Černý P., Hawthorne F.C. (1976) Refractive indices versus alkali contents in beryl: General limitations and applications to some pegmatitic types. Canadian Mineralogist, Vol. 14, pp. 491-497.

Da Silva M.R.R., Höll R., Beurlen H. (1995) Borborema Pegmatitic Province: Geological and geochemical characteristics. Journal of South American Earth Sciences, Vol. 8, Nos. 3/4, pp. 355-364, http://dx.doi.org/10.1016/0895-9811/95/00019-C.

de Donato P., Cheilletz A., Barres O., Yvon J. (2004) Infrared spectroscopy of OD vibrators in minerals at natural dilution: Hydroxyl groups in talc and kaolinite, and structural water in beryl and emerald. Applied Spectroscopy, Vol. 58, No. 5, pp. 521527, http://dx.doi.org/10.1366/000370204774103336.

Eidt T., Schwarz D. (1988) Die brasilianischen Smaragde und ihre
Vorkommen: Carnaíba/Bahia. Zeitschrift der Deutschen Gemmologischen Gesellschaft, Vol. 37, No. 1/2, pp. 31-47.

Epstein D.S. (1989) The Capoeirana emerald deposit near Nova Era, Minas Gerais, Brazil. GÆ G, Vol. 25, No. 3, pp. 150-158, http://dx.doi.org/10.5741/GEMS.25.3.150.

Giuliani G., Silva L.J.H.D., Couto P. (1990) Origin of emerald deposits of Brazil. Mineralium Deposita, Vol. 25, pp. 57-64.

Giuliani G., Cheilletz A., Zimmermann J-L., Ribeiro-Althoff A.M., France-Lanord C., Féraud G. (1997) Les gisements d'émeraude du Brésil: Genèse et typologie. Chronique de la Recherche Minière, Vol. 526, pp. 17-61.

Hänni H.A., Schwarz D., Fischer M. (1987) The emeralds of the Belmont mine, Minas Gerais, Brazil. Journal of Gemmology, Vol. 20, No. $7 / 8$, pp. 446-456.

Jacob D.E. (2006) High sensitivity analysis of trace element-poor geological reference glasses by laser-ablation inductively coupled plasma-mass spectrometry (LA-ICP-MS). Geostandards and Geoanalytical Research, Vol. 30, No. 3, pp. 221-235, http://dx.doi.org/10.1111/j.1751-908X.2006.tb01064.x.

Johnson M.L., Elen S., Muhlmeister S. (1999) On the identification of various emerald filling substances. $G \uplus G$, Vol. 35, No. 2, pp. 82-107, http://dx.doi.org/10.5741/GEMS.35.2.82.

Johnston W.D. Jr. (1945) Beryl-tantalite pegmatites of northeastern Brazil. Geological Society of America Bulletin, Vol. 56, pp. 10151070, http://dx.doi.org/10.1130/0016-7606(1945)56[1015:BPONB] 2.0.CO;2.

Kanis J. (2002) Piteiras, Brasilien; Erfolgreiche Smaragdsuche mit modernsten Methoden. Lapis, Vol. 27, No. 3, pp. 13-18.

Kiefert L., Hänni H.A., Chalain J.P., Weber W. (1999) Identification of filler substances in emeralds by infrared and Raman spectroscopy. Journal of Gemmology, Vol. 26, No. 8, pp. 487-500.

Milisenda C.C. (2007) Gemmologie Aktuell - New emerald deposit in Brazil. Gemmologie: Zeitschrift der Deutschen Gemmologischen Gesellschaft, Vol. 56, No. 3-4, p. 79.

Platonov A.N., Taran M.N., Minko O.E., Polshyn E.V. (1978) Optical absorption spectra and nature of color of iron-containing beryls. Physics and Chemistry of Minerals, Vol. 3, No. 1, pp. 87-88.

Rolff P.A.M.A. (1946) Minerais dos Pegmatitos da Borborema. DNPM/DFPM, Rio de Janeiro, Boletim 78, pp. 24-76.

Rondeau B., Notari F., Giuliani G., Michelou J-C., Martins S., Fritsch E., Respinger A. (2003) La mine de Piteiras, Minas Gerais, nouvelle source d'émeraude de belle qualité au Brésil. Revue de Gemmologie, No. 148, pp. 9-25.

Schmetzer K., Berdesinski W., Bank H. (1974) Über die Mineralart beryll, ihre farben und Absorptionsspektren. Zeitschrift der Deutschen Gemmologischen Gesellschaft, Vol. 23, No. 1, pp. 539.

Schmetzer K., Kiefert L., Bernhardt H.J., Zhang B. (1997) Charac- 
terization of Chinese hydrothermal synthetic emerald. $G \uplus G$, Vol. 33, No. 4, pp. 276-291, http://dx.doi.org/10.5741/GEMS. 33.4.276.

Scholz R. (2008) Preliminary Report on the Economic Potential Evaluation of Emerald Mineralization at Fazenda Bonfim. Mineração Vale Verde, internal report, DNPM - 848.044/2006; 848.057/07; 848.046/06 (in Portuguese, English translation by S. Cuberos Perez).

Schwarz D. (1990a) Die brasilianischen Smaragde und ihre Vorkommen: Santa Terezinha de Goiás/GO. Zeitschrift der Deutschen Gemmologischen Gesellschaft, Vol.39, No. 1, pp. 1344.

Schwarz D. (1990b) The Brazilian emeralds and their occurrences: Socotó, Bahia. Journal of Gemmology, Vol. 22, No. 3, pp. 147163.

Schwarz D. (1990c) Die Chemische Eigenschaften der Smaragde I. Brasilien. Zeitschrift der Deutschen Gemmologischen Gesellschaft, Vol. 39, No. 4, pp. 233-272.

Schwarz D. (1998) The importance of solid and fluid inclusions for the characterization of natural and synthetic emeralds. In D. Giard, Ed. L'émeraude, Association Française de Gemmologie, Paris, pp. 71-80.

Schwarz D., Hänni H.A., Martins F.L. Jr., Fischer M. (1988) Die Smaragde der Fazenda Boa Esperança bei Tauá, Ceará, Brasilien: Vorkommen und Charakteristika. Zeitschrift der Deutschen Gemmologischen Gesellschaft, Vol. 36, No. 3/4, pp. 133-147.

Seifert A.V., Zacek V., Vrana S., Pecina V., Zacharias J., Zwaan J.C. (2004) Emerald mineralization in the Kafubu area, Zambia. Bulletin of Geosciences, Vol., 79, No. 1, pp. 1-40.

Simmons W.B. (2007) Gem-bearing pegmatites. In L.A. Groat, Ed., Geology of Gem Deposits, Mineralogical Association of Canada,
Short Course Series, Vol. 37, pp. 169-206.

Souza J.L. (1988) Mineralogia e geologia da esmeralda da jazida de Itabira, Minas Gerais. Revista Escola de Minas, Vol. 43, No. 2, pp. 31-50.

Souza J.L., Mendes J.C., Silveira Bello R.M., Svisero D.P., Valarelli J.V. (1992) Petrographic and microthermometrical studies of emeralds in the 'garimpo' of Capoeirana, Nova Era, Minas Gerais State, Brazil. Mineralium Deposita, Vol. 27, pp. 161-168, http://dx.doi.org/10.1007/BF00197103.

Souza Neto J.A., Legrand J.M., Volfinger M., Pascal M.L., Sonnet P. (2008) W-Au skarns in the Neo-Proterozoic Seridó Mobile Belt Borborema Province in northeastern Brazil: An overview with emphasis on the Bonfim deposit. Mineralium Deposita, Vol. 43 pp. 185-205, http://dx.doi.org/10.1007/s00126-007-0155-1.

Wood D.L., Nassau K. (1968) The characterization of beryl and emerald by visible and infrared absorption spectroscopy. American Mineralogist, Vol. 53, pp. 777-800.

Zwaan J.C. (2001) Preliminary study of emeralds from the Piteiras emerald mine, Minas Gerais, Brazil. 28th International Gemmological Conference, Madrid, Spain, pp. 106-109.

Zwaan J.C. (2006) Gemmology, geology and origin of the Sandawana emerald deposits, Zimbabwe. Scripta Geologica, Vol. 131, pp. 1211

Zwaan J.C., Kanis J., Petsch E.J. (1997) Update on emeralds from the Sandawana mines, Zimbabwe. $G \uplus G$, Vol. 33, No. 2, pp. 80-100, http://dx.doi.org/10.5741/GEMS.33.2.80.

Zwaan J.C., Seifert A.V., Vrána S., Laurs B.M., Anckar B., Simmons W.B., Falster A.U., Lustenhouwer W.J., Muhlmeister S., Koivula J.I., Garcia-Guillerminet H. (2005) Emeralds from the Kafubu area Zambia. Gせ G, Vol.41,No. 2, pp. 116-148, http://dx.doi.org/10.5741/ GEMS.41.2.116.

For online access to all issues of GEMS \& GEMOLOGY from 1981 to the present, visit: 